\title{
Relationship between the Geotourism Potential and Function in the Polish Part of the Roztocze Transboundary Biosphere Reserve
}

\author{
Teresa Brzezińska-Wójcik (D)
}

Citation: Brzezińska-Wójcik, T. Relationship between the Geotourism Potential and Function in the Polish Part of the Roztocze Transboundary Biosphere Reserve. Geosciences 2021, 11, 120. https://doi.org/10.3390/ geosciences 11030120

Academic Editors: Jesus

Martinez-Frias and Aberra Mogessie

Received: 25 January 2021

Accepted: 4 March 2021

Published: 7 March 2021

Publisher's Note: MDPI stays neutral with regard to jurisdictional claims in published maps and institutional affiliations.

Copyright: (C) 2021 by the author. Licensee MDPI, Basel, Switzerland. This article is an open access article distributed under the terms and conditions of the Creative Commons Attribution (CC BY) license (https:/ / creativecommons.org/licenses/by/ $4.0 /)$.
Faculty of Earth Sciences and Spatial Management, Maria Curie-Sklodowska University, Al. Kraśnicka, 2d, 20-031 Lublin, Poland; tbrzezin@poczta.umcs.lublin.pl

\begin{abstract}
The Polish part of the Roztocze Transboundary Biosphere Reserve area is characterized by diversified geotourism resources with relatively high value. However, their potential seems not to be fully used in the current product offer. The aim of the study was therefore to assess the spatial variability of the geotourism potential and function and to determine their interrelations in view of further development of geotourism in the Roztocze TBR and the perspective of creation of the "Kamienny Las na Roztoczu" geopark. The study was carried out with the use of the taxonomic method of multidimensional comparative analysis consisting of calculation and analysis of general, total, and partial indices of the geotourism potential and function in 22 communes. The results showed the highest total indicator of geotourism potential in two communes, i.e., Józefów and Krasnobród, and the highest value of the total geotourism function index in Krasnobród. The results of the analysis of the relationships between the geotourism potential and function indicate that the geotourism resources and products are fully used in terms of the development of the function only in Krasnobród commune. In turn, the value of the total geotourism function index in the Zwierzyniec commune exceeds the geotourism potential indicator, which implies that this area is overloaded by tourist movement. The total indicators of geotourism potential in the other communes, especially Józefów, Krasnobród, Lubycza Królewska, and Susiec, indicate the possibility of more intensive exploitation of geotourism resources in preparation of interesting products in compliance with the principles of sustainable development and, consequently, the development of the geotourism function.
\end{abstract}

Keywords: geotourism resources; geotourism product; multidimensional comparative analysis; Roztocze Transboundary Biosphere Reserve; Kamienny Las na Roztoczu geopark project

\section{Introduction}

The development of various forms of nature-related tourism in protected areas has a long tradition/history [1]. It includes the activities in Biosphere Reserves [2] focused on the popularization and promotion of their resources carried out since 1977 [3-6]. These activities are especially relevant in regions that have not developed a coherent brand to attract tourists [7] not only to specific recognizable objects but also to interesting but less known ones. An example of such an area is the Polish part of the Roztocze region [8], which has been protected as the Roztocze Transboundary Biosphere Reserve (Roztocze TBR) since 19 June $2019[9,10]$.

Geotourism in areas covered by Man and the Biosphere (MAB) Programme protection is part of the popular ecotourism trend [11] and a form of sustainable tourism [12-14], which favors geological education and benefits the local community in a holistic way $[15,16]$. In addition, it promotes knowledge of the geological and geomorphological features of the area and the related tourism products (attractions). Geotourism also includes many aspects of other activities, e.g., transport, accommodation, planning, management, and complementary/additional services [17,18], which are important for sustainable development.

A review of the current literature [19-21] indicates that the vast majority of authors employ an empirical approach to evaluation of geotourism resources constituting the 
potential for geotourism development. In turn, fewer authors analyze the extent to which this form of tourism supports the development of local communities and highlight the development of geotourism in terms of sustainability of the region [22,23]. In the latter context, many authors (e.g., [14-16,24]) emphasize the importance of geotourism resources as a basis for creation of an interesting geotourism product $[25,26]$. Product-based geotourism contributes to the economic development of regions, inducing positive changes in residents' awareness of geotourism resources [27], as well as in in protected areas [14].

In the broad-sense tourism context, the Polish part of the Roztocze region has already been assessed, e.g., in terms of the diversification of the tourism potential and function [28], taking into account all nature resources. Nevertheless, the following questions arise: (1) the extent to which geotourism resources and related products determine the geotourism function in the 22 communes included in the Roztocze TBR and (2) the possibilities of exploitation of the geotourism potential in the context of sustainable development of the area, with the perspective of creating the "Kamienny Las na Roztoczu" geopark (Figure 1) within its borders.

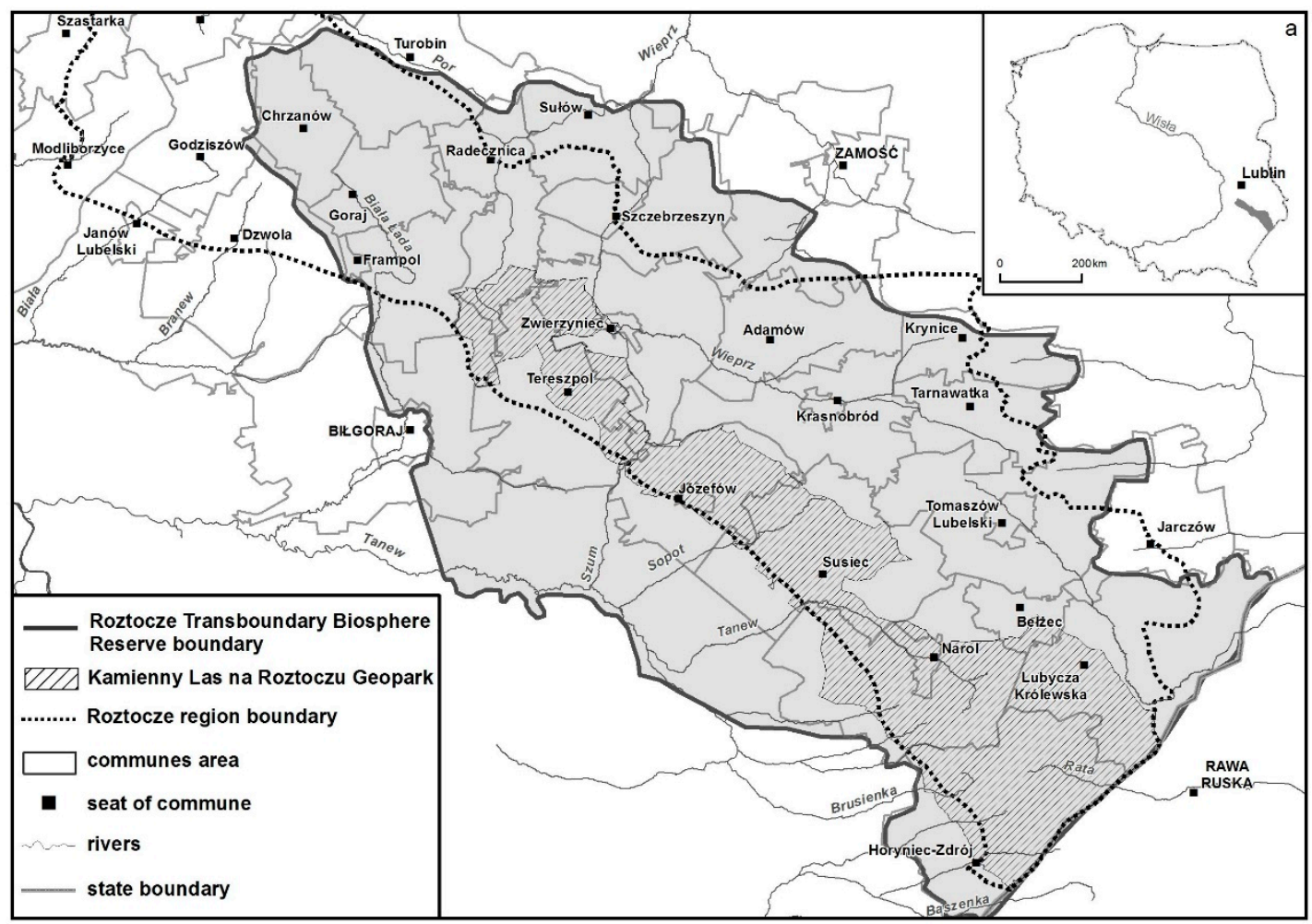

Figure 1. Location of the Polish part of the Roztocze Transboundary Biosphere Reserve [9,10] and the "Kamienny Las na Roztoczu" geopark project [29] against the border of the Roztocze region [8].

\section{Materials and Methods}

\subsection{Geotourism Resources of the Roztocze TBR}

In administrative terms, the Roztocze TBR area covers 22 communes located within the borders of the Polish part of the physico-geographical region of Roztocze (Figure 1, Figure 2a).

In terms of geology, the area of the Polish part of the Roztocze TBR is located within the Trans-European Suture Zone [30]. It was unevenly elevated in the late MiocenePliocene as a large-scale flower structure rooted into deep substrate (Figure $2 b$ ). The formations exposed on the Roztocze surface are dominated by Late Cretaceous carbonate and carbonate-siliceous rocks (93-65 million years ago) [31,32]. These are marine sediments (gaize-glauconitic sandstone, opoka-calcium carbonate and silica rock formed by, i.e., Bryozoa, Bivalvia, Echinoidea, coccoliths), with numerous fossils of cephalopods, scaphopods, 
bivalves, brachiopods, and fish scales. There are quite numerous crustacean burrows (Figures 2 and 3).

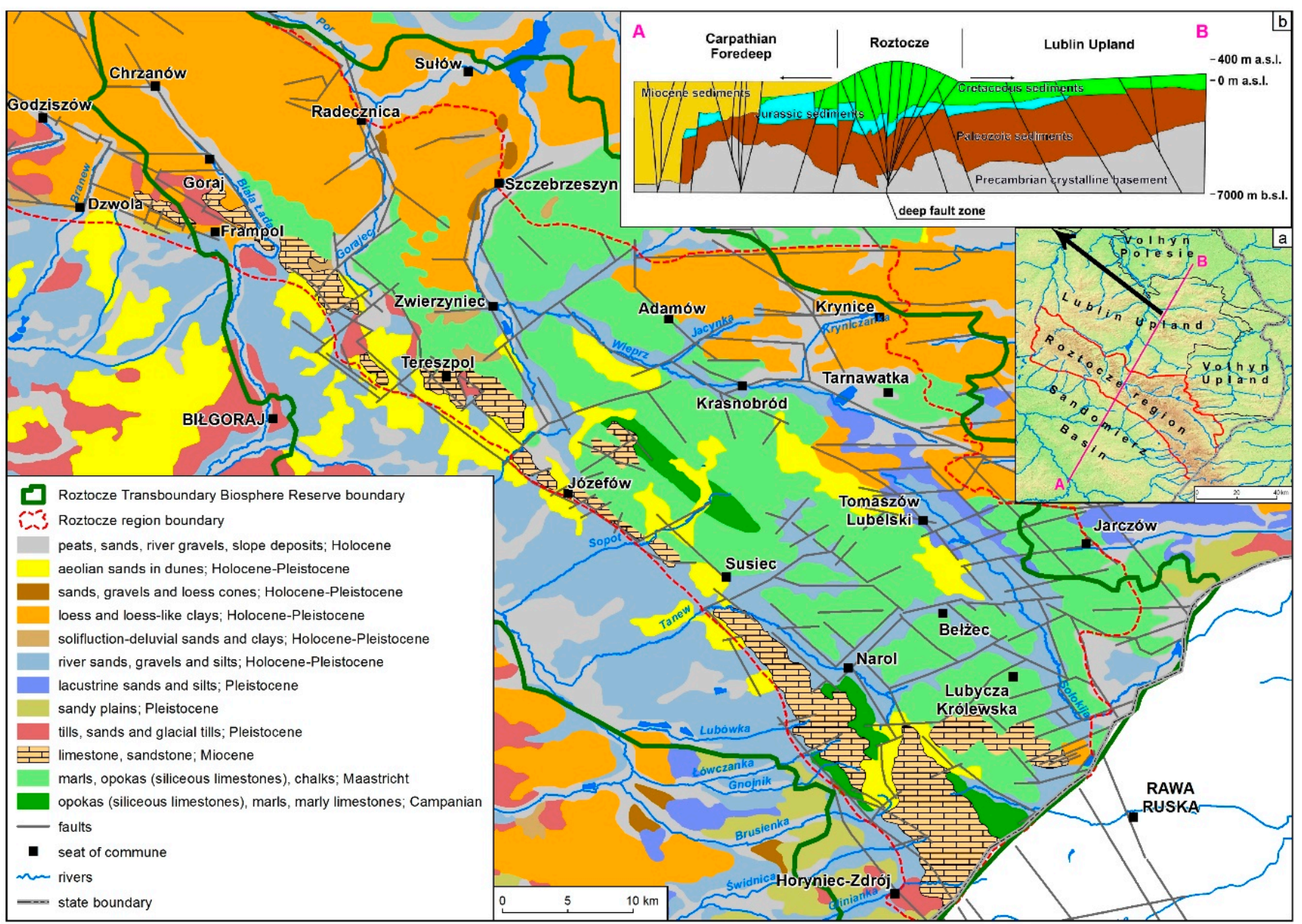

Figure 2. Geological characteristics of the Polish part of the Roztocze Transboundary Biosphere Reserve according to Malinowski, Mojski [31], Rzechowski, Kubica [32]; (a) Boundaries of the Roztocze region according to Solon et al. [8]; (b) schematic crosssection through the Roztocze region as a flower structure according to Jankowski, Margielewski [33], Cieśliński et al. [34].

The Cretaceous rocks are covered by heavily eroded shallow water sediments of Paleogene (Eocene, 55-34 million years ago) and Neogene (Miocene, 8-12 million years ago) seas. The Eocene formations, sands, and sandstones, are characteristic for the eastern part, whereas the younger Miocene limestones (Figures 2 and 4), coquina beds, sands, and sandstones are typical for the southwestern part of the area $[35,36]$. A unique resource on a national scale are the fragments of petrified Miocene Taxodioxylon taxodii wood from the family Cupressaceae [37] in the south-eastern part of the area.

Pleistocene deposits are present only on hills (residual moraine covers of Mindel and Riss glaciations) and in deep valleys (sands, gravels, and clays with a thickness of over $30 \mathrm{~m}$ ) [38,39]. Aeolian formations, i.e., loess covers, are typical in the north-western part of the Roztocze TBR, whereas sands, also forming dunes, are characteristic for the depressions and valleys in its central part (Figure 2). 


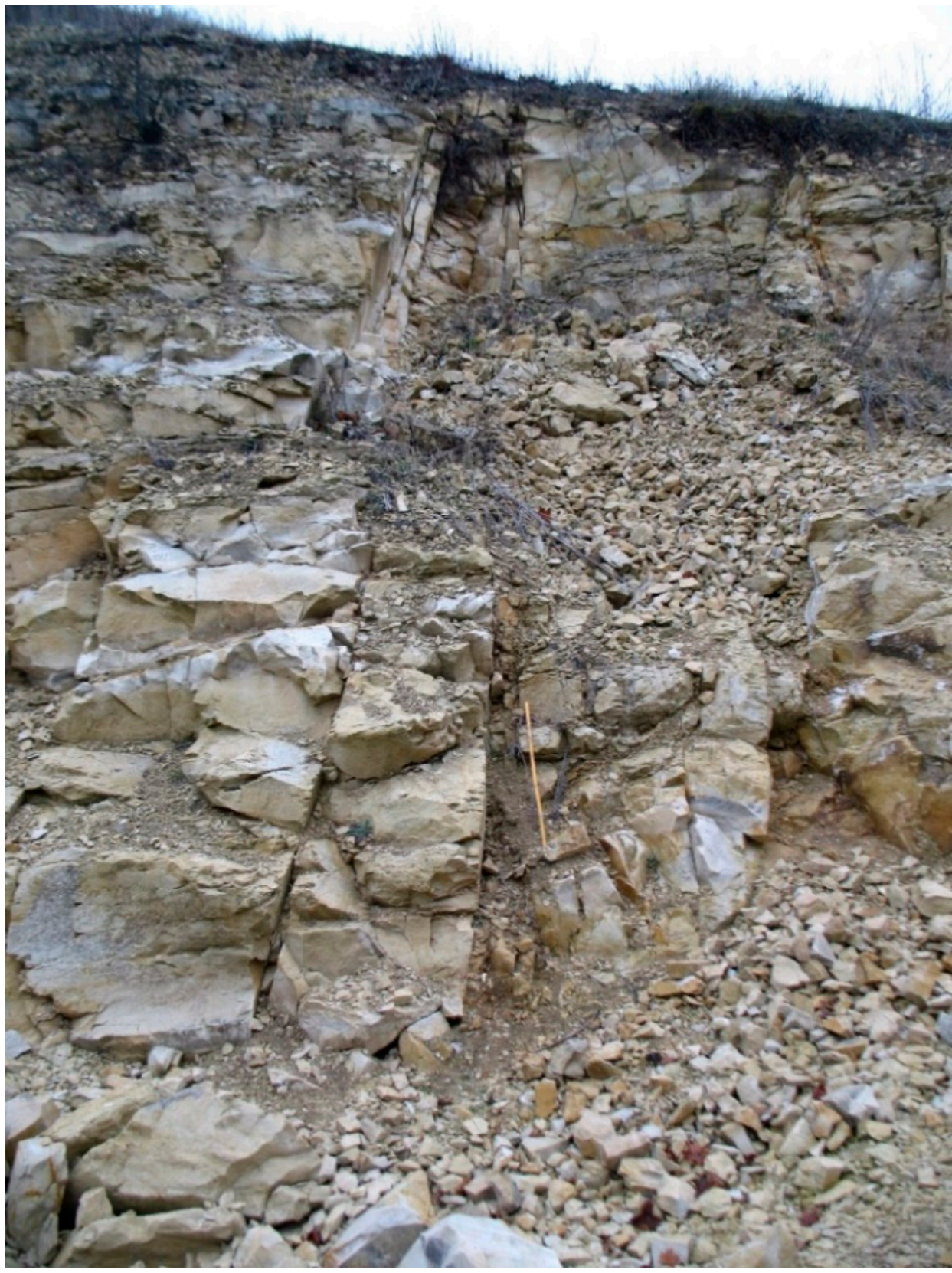

Figure 3. Late Cretaceous opokas in Krasnobród quarry with fossils of: (a) coniferous plant Geinitzia, (b) leafy plant Debeya paulinae [40,41], (c) Belemnitella junior Nowak, (d) Hoploscaphites constrictus [42].

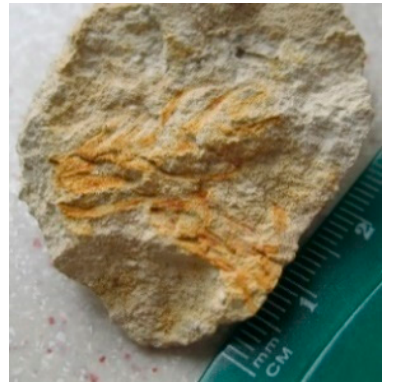

(a)

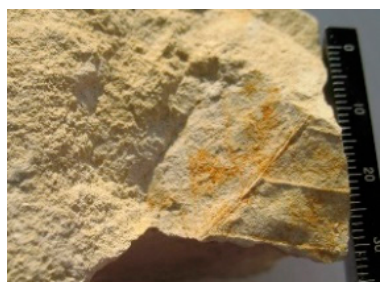

(b)

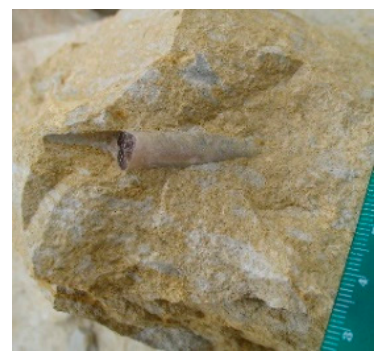

(c)

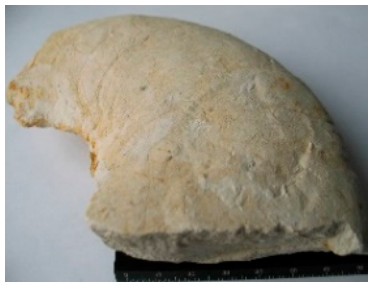

(d)

The analyzed area exhibits a diversified topography. The elevations vary from approximately $330 \mathrm{~m}$ a.s.l. in the north-western part, through $360 \mathrm{~m}$, to approximately $390 \mathrm{~m}$ in the south-eastern part. The north-western and south-eastern parts, i.e., the Por and Biała Łada interfluve, the south-western Roztocze escarpment zone between Łówcza and Horyniec-Zdrój, and the Tanew, Sołokija, and Raty interfluve, are characterized by the highest maximum denivelation values $(>78.0 \mathrm{~m})$ [43]. This diversity is emphasized by the presence of residual hills, rocks and their groups, river valleys, steep rapids (cascades) in riverbeds, ravine valleys in Miocene rocks, caves, gullies in the loess cover, and spring niches. 

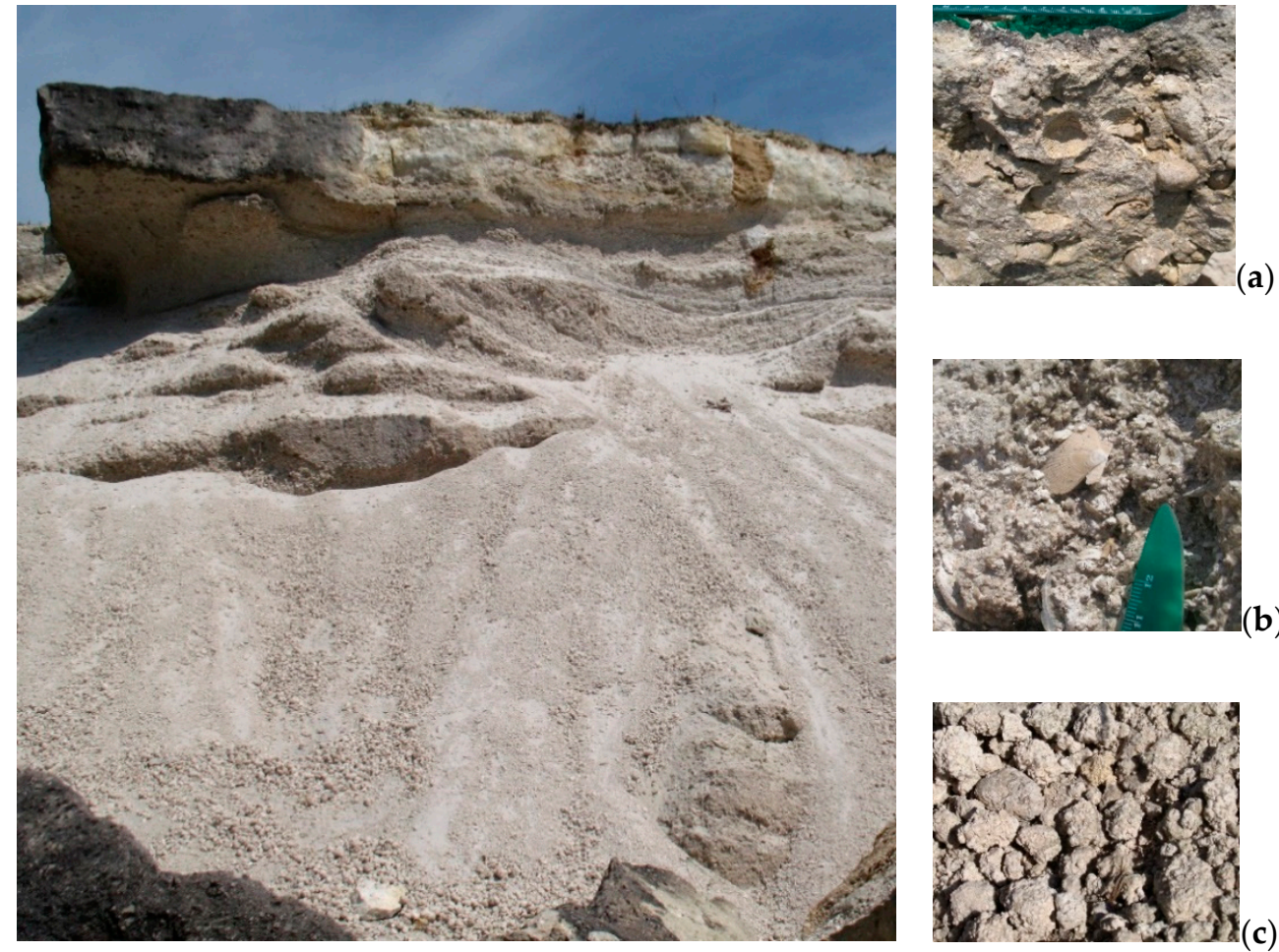

(a)
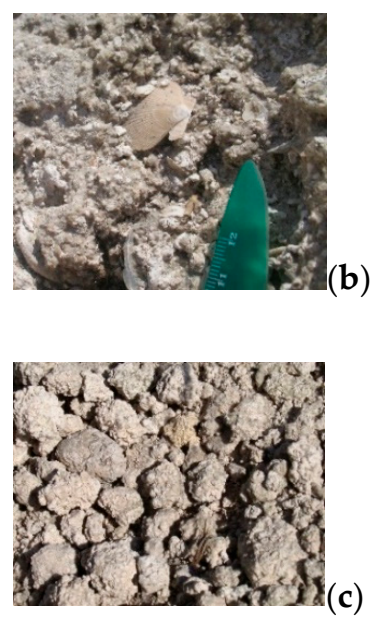

Figure 4. Miocene Lithothamnium limestones in Huta Różaniecka quarry: (a) bivalve casts and shells (a coquina bed) [36], (b) serpulid-microbial limestones with Chlamys scallop shells [44], (c) rhodoliths of up to $4 \mathrm{~cm}$ diameter [36].

The residual hills vary in their altitudes: Wielka Jeżówka (337.5 m a.s.1.) and Grabowa Góra (332.2) in the north-western part of the Roztocze Transboundary Biosphere Reserve, Góra Kamień (348.0) (Figure 5a,b), Popilarka (358.1), and Wapielnia (386.5) in the central part, and Kragły Goraj (388.7), Wielki Dział (390.5), and Długi Goraj (391.5 m a.s.1.) in the southeastern part of the area. The hills are often associated with rocks or groups of rocks. Most of them are located in the south-eastern part of the analyzed area, e.g., Diabelski Kamien in Dahany, Diabelskie Kamienie in Werchrata, and "Kopiec termitów" in the non-existent Zajace village (Figure 5c,d) [45].

The valleys of the Szum, Sopot, Jelenia, and Tanew Rivers are the characteristic features in the central part of the Roztocze TBR. They dissect the south-western escarpment zone of the Roztocze region. Their beds have steep rapids: waterfalls in Campanian gaize facies in the Szum riverbed, three sequences in Campanian gaizes and one in Miocene organodetrital limestones in the Sopot riverbed, four sequences in the Tanew and one in the Jelen (Figure 5e,f) in Campanian gaizes [46]. The valleys of the Biała Łada, Gorajec, and Wieprz Rivers are interesting in terms of landscape value. The riverbeds of some of the rivers, e.g., the Wieprz valley, form large-radius meanders $(6.3-115.0 \mathrm{~m})$. The fragment of the Wieprz River valley located in the half-graben zone is characterized by an asymmetrical cross-section. The left slope is long and gently sloping, while the right slope is short and steep. At the bottom of the valley, there are characteristic peat bogs, a complicated system of Holocene riverbeds, and the meandering Wieprz riverbed (Figure 6a,b) [47]. Proluvial cones contribute to the local narrowing and the higher slope of the valley bottom $[39,48]$. 

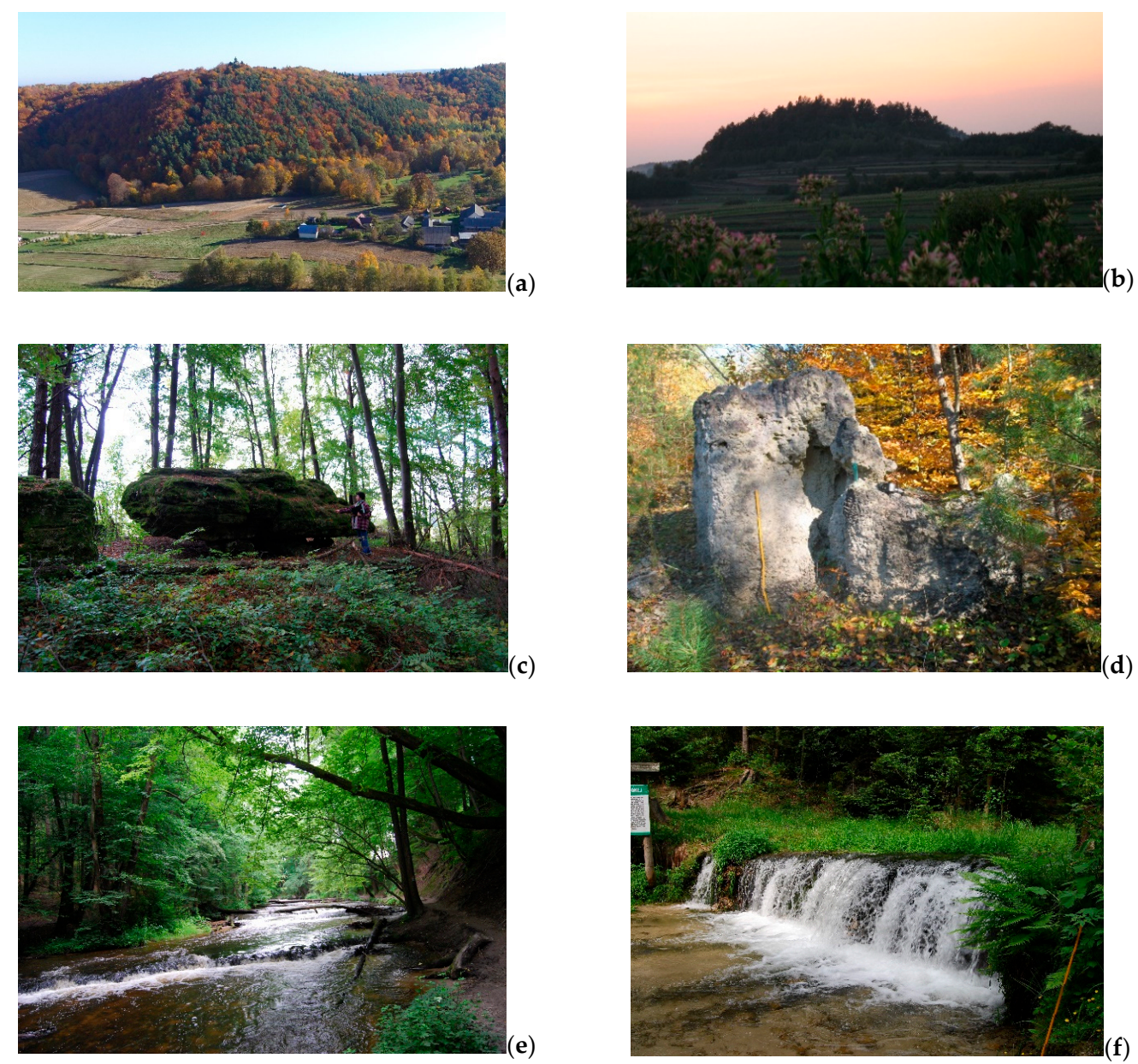

Figure 5. Examples of landforms: (a) Czubatka Hill, (b) Kamienna Hill, (c) Diabelskie Kamienie rocks in Werchrata, (d) "Kopiec termitów" rock in the non-existent Zające village, (e) waterfalls in the Tanew River, (f) waterfall in the Jeleń river.
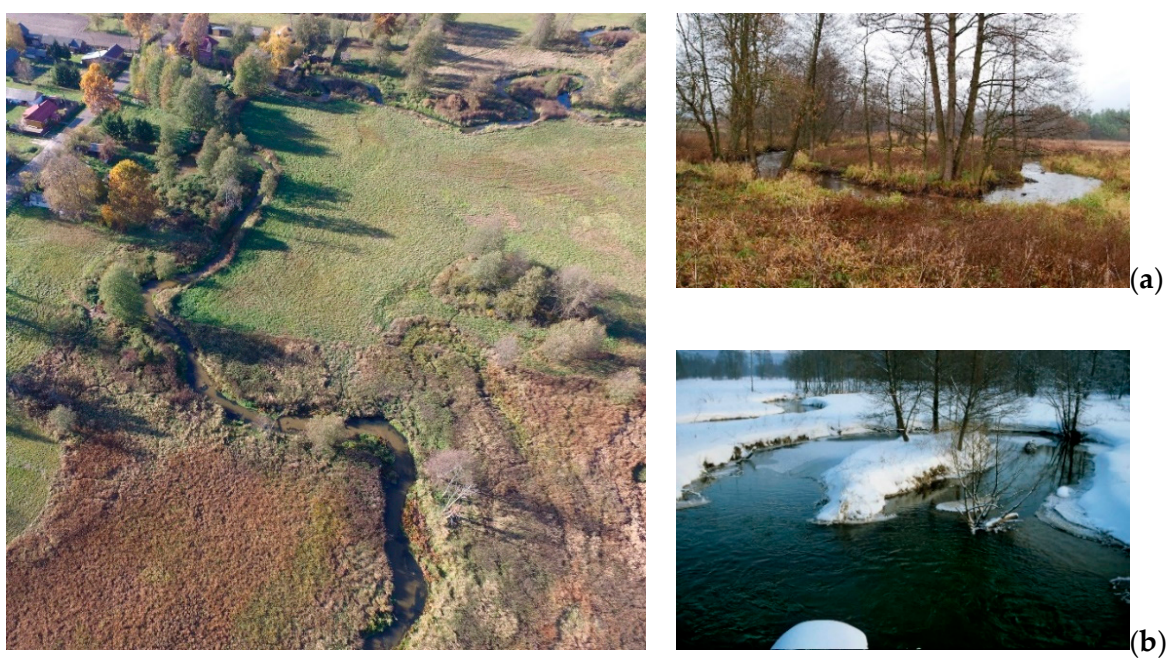

Figure 6. The riverbed of the Wieprz valley near Guciów: (a) large-radius meander in spring, (b) large-radius meander in winter.

Ravines (Łówczanka, Dubleń, Sopot Mały Rivers) (Figure 7a) and caves (e.g., Jaskinia Diabelska, Jaskinia w Niedźwiedziach) in Miocene limestones and sandstones [45,46] are typical forms in the south-eastern part of the Roztocze TBR. 


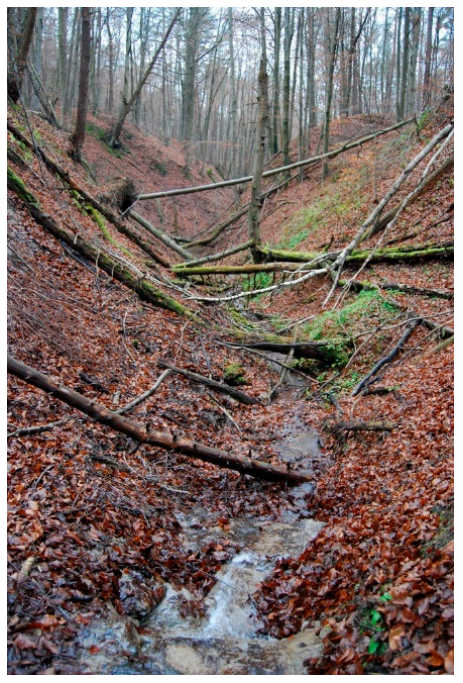

(a)

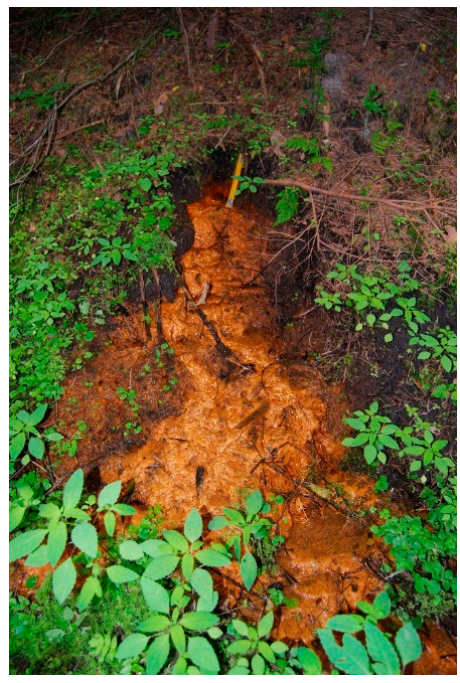

(b)

Figure 7. Examples of landforms: (a) Dubleń Ravines, (b) spring niche of ferruginous water.

Gullies dissecting the loess cover are characteristic for the north-western part of the Roztocze TBR. They exhibit different stages of development: from young to mature wellestablished forms. Their bottoms are $20 \mathrm{~m}$ wide and their slopes are several meters high. The gullies form branched several kilometer long systems with an average density of $9 \mathrm{~km} / \mathrm{km}^{2}$ in the so-called "Piekiełko" near Szczebrzeszyn, which is the largest in the analyzed area [49].

The upper sections of almost all valleys are associated with spring niches supplying bicarbonate-calcium waters to the Por River in Radecznica, the Wieprz River in Krasnobród, the Tanew River in Dębiny, and the Świdnica River in Nowiny Horynieckie as well as ferruginous waters to the Jelen River (Figure 7b) in the Roztocze escarpment zone (Susiec commune) [50]. Sulfide waters $\left(\mathrm{HCO}_{3}-\mathrm{Ca}-\mathrm{SO}_{4}\right)$ are characteristic only for the surroundings of Horyniec-Zdrój [51].

\subsection{Materials}

The achievement of the research goals required the use of primary and secondary sources of data and appropriate methods.

The data on the type, number, and spatial distribution of geotourism resources were obtained directly with the field inventory method in 2012-2019. The results of the inventory carried out as part of the "Kamienny Las na Roztoczu" geopark project [29], which was co-designed by the author of this study, were used as well [52].

The information on geotourism products offered in the analyzed communes was provided by secondary source materials, including the websites of the Roztocze National Park [53], Landscape Parks [54], Local Tourist Organizations-LTO Roztocze and LTO Zamość and Roztocze [55,56], local governments, individual entities, associations [57], and the Polish Tourist and Sightseeing Society [58]. The research covered only museums and educational centers presenting geotourism resources and touristic trails along at least one geotourism facility.

The number of tourists was determined based on data from primary and secondary sources. Direct information was obtained from organizers of tourist events, e.g., trekking events $[57,58]$. The information from secondary sources included the number of tickets sold to the Roztocze National Park, data from pyroelectric sensors installed along educational trails leading to/running through geosites (steep rapids in "Czartowe Pole" and "Nad Tanwią" reserves), records from tourist information centers in Józefów, Krasnobród, Lubycza Królewska, Susiec, Szczebrzeszyn, Tomaszów Lubelski, Horyniec-Zdrój, and Zwierzyniec communes [59-62] and museums [63-66], data from LTO Roztocze and LTO Zamość and Roztocze, and websites of tour operators e.g., the Polish Tourist and Sightseeing Society. 


\subsection{Methods}

To date, the analysis of strengths and weaknesses, opportunities and threats (SWOT) method has been employed most frequently to assess the extent of the exploitation of geotourism resources in the product/offer of the area $[67,68]$. Statistical methods based on the use of GIS tools have been applied in only few studies [69]. In the present study, a taxonomic method of multivariate comparative analysis [70] was applied for the assessment of the Roztocze TBR area. This approach was used previously for general evaluation of the tourism potential and function of the Roztocze region [28]. It is based on the model proposed by G. Gołembski et al. [71] and facilitates linear ordering of objects (communes) described by many diagnostic variables, which are replaced by one synthetic variable, i.e., the total index of analyzed features.

The research procedure consisted of five stages (Figure 8): (1) meta-analysis of literature-based discovery; (2) definition of diagnostic variables of the geotourism potential and function; (3) inventory and query of geotourism potential and function; (4) calculation of geotourism potential and function indices with the multidimensional comparative analysis methodology; (5) analysis and synthesis of the results to indicate the possibilities of a more complete use of the geotourism potential in the context of the sustainable development of the area with the prospect of establishment of the "Kamienny Las na Roztoczu" geopark.

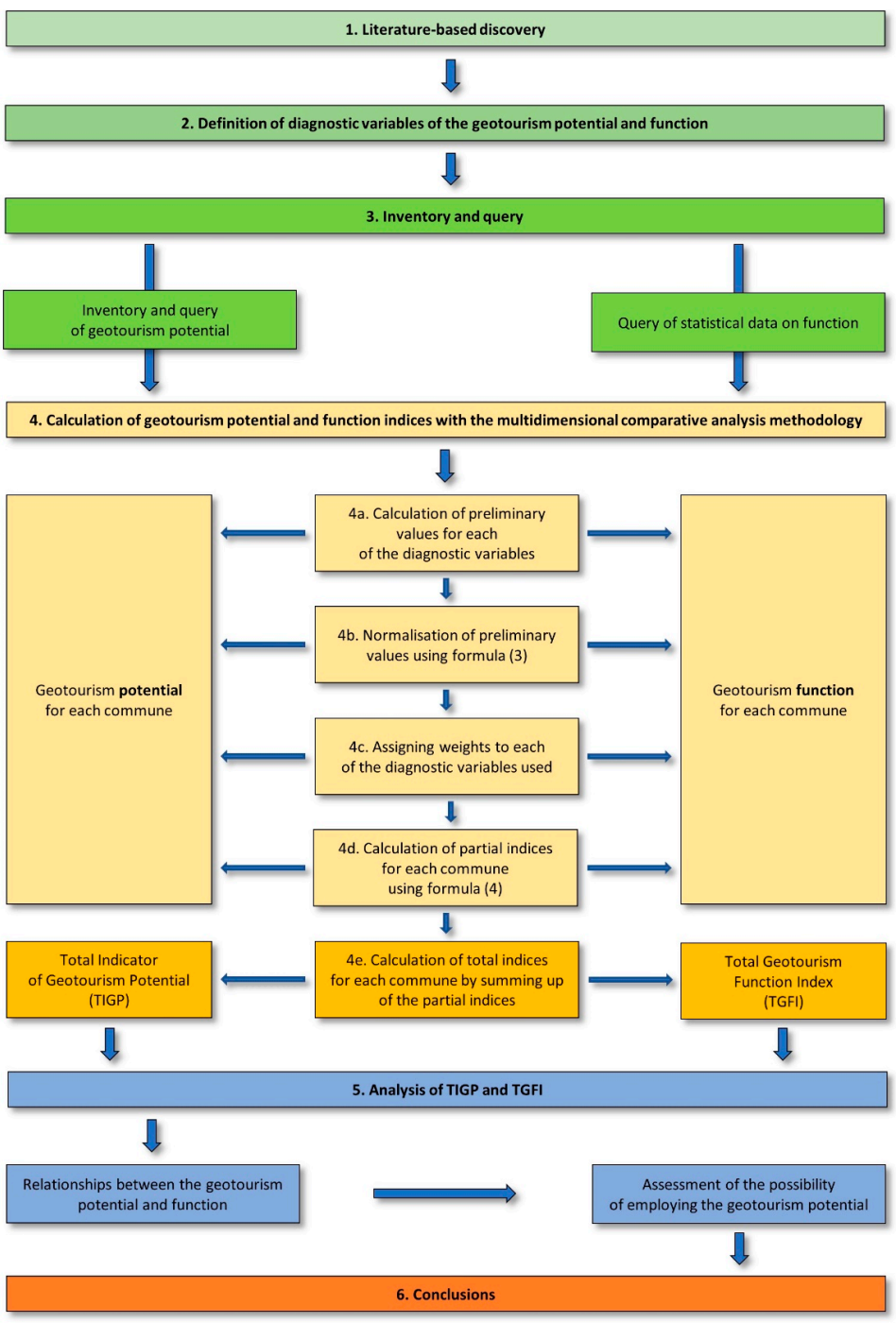

Figure 8. Research procedure scheme. 
In the present study, the geotourism resources (potential) denote the geological and geomorphic diversity in its normal sense [72,73]. Geotourism products based on such resources were regarded as the potential as well.

The development of the geotourism function was determined based on the number of tourists exploiting the geotourism resources and/or products associated with these resources. This measure was indicated by the results of a review of literature on the definition of the tourism function [74] and its measures proposed by M. Durydiwka [75]. The classical indicators (e.g., Baretje, Defert) were not used to define the tourism function, as they would have had very small values that would have been difficult to use in the comparative analysis of the communes. This in turn would have impeded the determination of the degree of diversification of the tourist function in the analyzed administrative units, as suggested by M. Durydiwka [75]. The following matrix was the basis for the arrangement of the variables in the 22 communes:

$$
X i j=\left[\begin{array}{ccc}
x 1 & \ldots & x 3 \\
\ldots & \ldots & \ldots \\
x n 1 & \ldots & x n m
\end{array}\right]
$$

where $X i j$ is the value of the $j$ variable in the $i$-th commune.

It was assumed that all analyzed variables stimulate the development of geotourism; hence, the initial position $x j$ is a stimulant, so it becomes $y j$ without conversion:

$$
y i j=x i j
$$

where $I$ is the commune number $(i=1, \ldots, m), j$ is the item number $(j=1, \ldots, \mathrm{n}), x i j$ is the value of feature $j$ in the $i$-th commune, yij is the value of a stimulant item $j$ in the $i$-th commune.

In the first stage, 22 diagnostic variables (features) grouped into two spheres and five sections were used to assess the potential and functions for each commune (Table 1).

Table 1. Diagnostic variables of the potential and function grouped into spheres and sections with adopted measures and weight units.

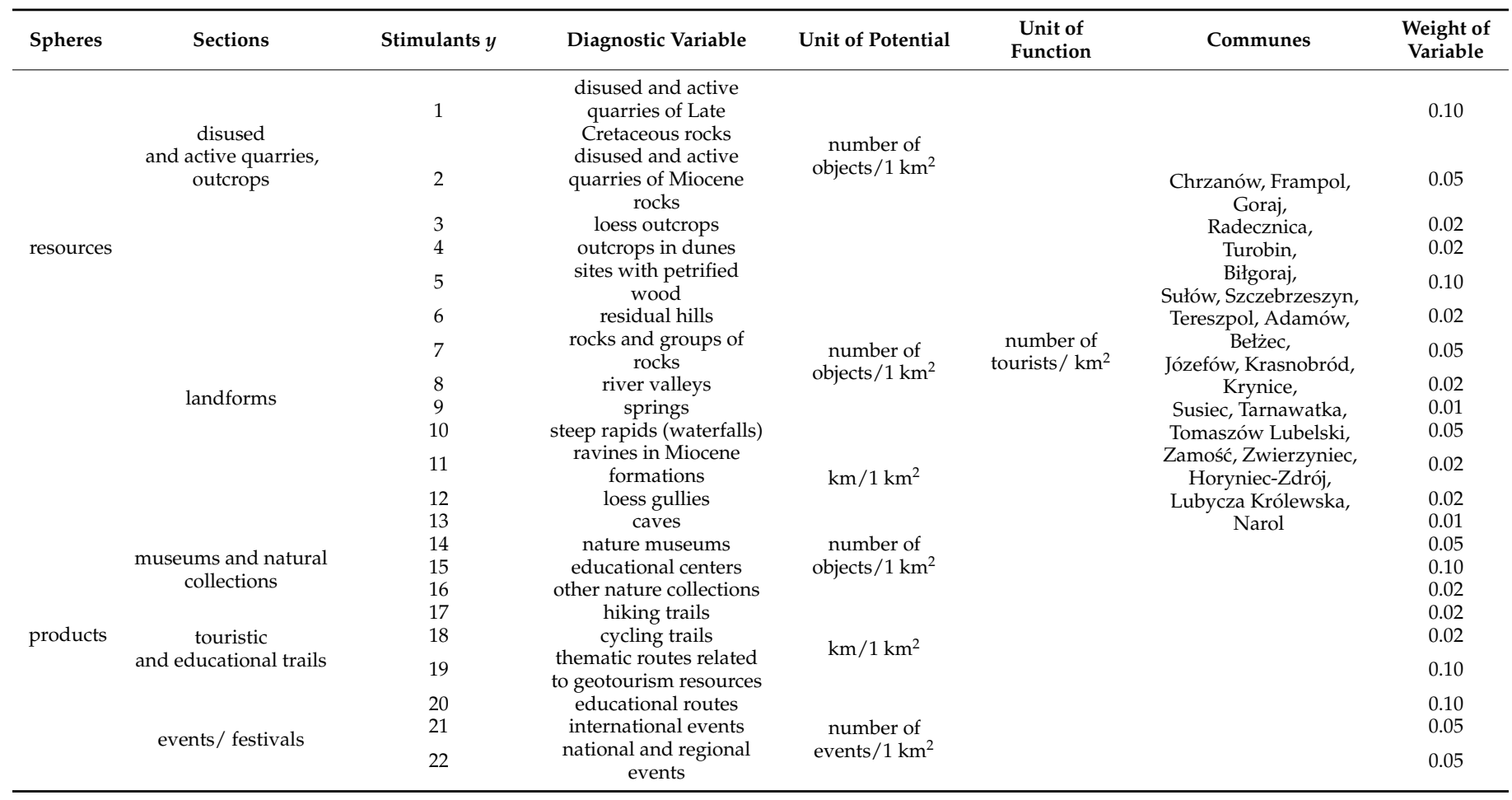


Next, the numerical values of the diagnostic variables adopted for the assessment of the geotourism potential and function were juxtaposed with the area of each of the 22 communes [76] located in the area of the Roztocze TBR (Table 2).

Table 2. Preliminary values of the geotourism potential in some communes.

\begin{tabular}{|c|c|c|c|c|c|}
\hline \multirow{2}{*}{ Sections } & \multirow{2}{*}{ Stimulants $y$} & \multirow{2}{*}{$\begin{array}{c}\text { Diagnostic } \\
\text { Variable }\end{array}$} & \multicolumn{3}{|c|}{ Preliminary Values of Features in Communes } \\
\hline & & & Chrzanów & Frampol & Goraj \\
\hline \multirow{5}{*}{$\begin{array}{c}\text { disused } \\
\text { and active quarries, } \\
\text { outcrops }\end{array}$} & 1 & $\begin{array}{l}\text { disused and active } \\
\text { quarries of Late } \\
\text { Cretaceous rocks }\end{array}$ & 0.014 & 0.000 & 0.015 \\
\hline & 2 & $\begin{array}{c}\text { disused and active } \\
\text { quarries of } \\
\text { Miocene rocks }\end{array}$ & 0.000 & 0.009 & 0.015 \\
\hline & 3 & loess outcrops & 0.000 & 0.009 & 0.030 \\
\hline & 4 & outcrops in dunes & 0.000 & 0.000 & 0.000 \\
\hline & 5 & $\begin{array}{l}\text { sites with petrified } \\
\text { wood }\end{array}$ & 0.000 & 0.000 & 0.000 \\
\hline
\end{tabular}

In the subsequent stage, the calculated values of the diagnostic variables expressed in different units were made comparable [71] with the method of quotient transformation. The maximum value of each of the variables obtained for the analyzed communes was adopted as a reference point. The variables were normalized using Equation (3).

$$
n_{i j}=y_{i j} / y_{j \max },
$$

where $y_{i j}$ is the initial value of each diagnostic variable in the $i$-th commune, $y_{j m a x}$ is the highest value of the initial diagnostic variable in the $i$-th commune.

Some examples of variable normalization results are presented in Table 3.

Table 3. Normalized values of the tourism potential elements in some communes.

\begin{tabular}{|c|c|c|c|c|c|}
\hline \multirow{2}{*}{ Sections } & \multirow{2}{*}{$y$} & \multirow{2}{*}{ Diagnostic Variable } & \multicolumn{3}{|c|}{ Normalized Values of Features in Communes } \\
\hline & & & Chrzanów & Frampol & Goraj \\
\hline \multirow{5}{*}{$\begin{array}{l}\text { disused } \\
\text { and active } \\
\text { quarries, } \\
\text { outcrops }\end{array}$} & 1 & $\begin{array}{l}\text { disused and active quarries } \\
\text { of Late Cretaceous rocks }\end{array}$ & 0.875 & 0.000 & 0.938 \\
\hline & 2 & $\begin{array}{c}\text { disused and active quarries } \\
\text { of Miocene rocks }\end{array}$ & 0.000 & 0.093 & 0.155 \\
\hline & 3 & loess outcrops & 0.000 & 0.009 & 0.030 \\
\hline & 4 & outcrops in dunes & 0.000 & 0.000 & 0.000 \\
\hline & 5 & sites with petrified wood & 0.000 & 0.000 & 0.000 \\
\hline
\end{tabular}

Thus, all the normalized values of the variables were in the range of $0.000-1.000$ (where 1.000 was the highest normalized value of the analyzed variable for the communes and 0.000 was the lowest value).

In the next stage, weights (importance ranks) were assigned to the diagnostic variables of the potential and function (Table 1) as proposed by G. Gołembski et al. [71]. The touristic, scientific, and educational attractiveness of the features defined by the authors of geosite cards presented on https:/ / cbdgportal.pgi.gov.pl/geostanowiska/ (accessed on 20 November 2020) [45] was taken into account. The sum of weights assigned to the variables was 1.000, with 0.500 for each for the two spheres: resources and products.

Assigning weights to particular features is the most subjective part of the method employed. The use of weights results from the belief that individual variables, which are partial evaluation criteria, have varied relevance in the final evaluation of the area. However, despite the subjectivity in assigning weights, the relatively large number of features adopted in the study facilitates elimination of the effects of possible erroneous assumptions, as indicated by e.g., S. Greco et al. [70] and G. Gołembski et al. [71]. 
The next step consisted in calculation of partial indices of the potential and function of each of the diagnostic variables as the ratio of each normalized value describing the variable and its assigned weight-using Equation (4).

$$
M_{i j}=n_{i j} x w_{j}
$$

where $M_{i j}$ is the synthetic measure in the $i$-th commune, $n_{i j}$ is the normalized value of item $j$ in the $i$-th commune, and $w_{j}$ is the weight assigned to diagnostic variable $j$.

Examples of the values of the partial indices are shown in Table 4.

Table 4. Examples of partial indices of the geotourism potential calculated for the disused and active quarries and outcrops section in some communes.

\begin{tabular}{cccccc}
\hline \multirow{2}{*}{ Sections } & $y$ & Diagnostic Variable & \multicolumn{2}{c}{ Partial Indices of Features in Communes } \\
\cline { 5 - 6 } & 1 & $\begin{array}{c}\text { disused and active quarries } \\
\text { of Late Cretaceous rocks }\end{array}$ & 0.088 & Frampol & Goraj \\
\hline $\begin{array}{c}\text { disused } \\
\text { and active }\end{array}$ & 2 & $\begin{array}{c}\text { disused and active quarries } \\
\text { quarries, }\end{array}$ & 0.000 & 0.000 & 0.094 \\
outcrops & 3 & $\begin{array}{c}\text { loess outcrops } \\
\text { outcrops in dunes }\end{array}$ & 0.000 & 0.006 & 0.001 \\
& 4 & sites with petrified wood & 0.000 & 0.000 & 0.000 \\
\multicolumn{2}{c}{ Summary indicator for the section } & 0.088 & 0.000 & 0.000 \\
\hline
\end{tabular}

In the next stage, combined indices of the potential and function were calculated for the adopted sections and spheres, then, the Total Indicator of Geotourism Potential (TIGP) and the Total Geotourism Function Index (TGFI) were calculated for each of the 22 communes. These calculations consisted of summing up the values of the partial indices of all diagnostic variables within the five sections (Table 4) and the two spheres distinguished in each of the communes.

The indices of the geotourism potential (TIGP) and function (TGFI) were classified in a five-point numerical-concept scale. The calculated value of 0.060 , i.e., half of the arithmetic mean value for the obtained data set, was used to distinguish the classes of the geotourism potential and function in the communes (Table 5).

Table 5. Criteria for classification of geotourism potential and function.

\begin{tabular}{|c|c|c|}
\hline $\begin{array}{c}\text { Values } \\
\text { of the Total Indices of the Geotourism }\end{array}$ & \multicolumn{2}{|c|}{ Interpretation } \\
\hline Geotourism Function (TGFI) & Potential & Function \\
\hline$>0.184$ & very high & very well developed \\
\hline $0.123-0.183$ & high & well developed \\
\hline $0.061-0.122$ & moderate & moderately developed \\
\hline $0.001-0.060$ & low & poorly developed \\
\hline 0.000 & none & not developed \\
\hline
\end{tabular}

The values of the total indicators (TIGP, TGFI) assigned to separate classes helped to distinguish communes with a specific geotourism potential and those with a varied degree of development of the geotourism function (Tables 7-15). The values were compared in a two-dimensional space (Figure 9). 


\section{Results}

The calculated values of the Total Indicator of Geotourism Potential and the Total Geotourism Function Index allowed for the assessment of the diversity of the current geotourism potential and function in the 22 communes in the Roztocze TBR area.

\subsection{Diversity of the Geotourism Potential in the Roztocze TBR}

Very high geotourism potential (TIGP > 0.184) was determined for 7 of the 22 analyzed communes: Józefów, Krasnobród, Susiec, Lubycza Królewska, Szczebrzeszyn, Tereszpol, and Goraj (Table 6).

Table 6. Diversity of the geotourism potential of communes located within the Roztocze TBR shown by the Total Indicator of Geotourism Potential TIGP.

\begin{tabular}{|c|c|c|c|c|c|c|c|c|c|}
\hline \multicolumn{10}{|c|}{ Geotourism Potential } \\
\hline \multicolumn{2}{|c|}{ Very High } & \multicolumn{2}{|c|}{ High } & \multicolumn{2}{|c|}{ Moderate } & \multicolumn{2}{|c|}{ Low } & \multicolumn{2}{|c|}{ None } \\
\hline Communes & $\begin{array}{c}\text { TIGP > } \\
0.184\end{array}$ & Communes & $\begin{array}{c}\text { TIGP } \\
0.123-0.183\end{array}$ & Communes & $\begin{array}{c}\text { TIGP } \\
0.061-0.122\end{array}$ & Communes & $\begin{array}{c}\text { TIGP } \\
0.001-0.060\end{array}$ & Communes & $\begin{array}{l}\text { TIGP } \\
0.000\end{array}$ \\
\hline Józefów & 0.457 & Horyniec-Zdrój & 0.183 & Chrzanów & 0.118 & Narol & 0.049 & Tarnawatka & 0.000 \\
\hline Krasnobród & 0.285 & Zwierzyniec & 0.134 & Radecznica & 0.093 & Bełżec & 0.041 & & \\
\hline Susiec & 0.257 & & & Adamów & 0.072 & $\begin{array}{l}\text { Tomaszów } \\
\text { Lubelski }\end{array}$ & 0.036 & & \\
\hline $\begin{array}{l}\text { Lubycza } \\
\text { Królewska }\end{array}$ & 0.242 & & & & & Krynice & 0.034 & & \\
\hline Szczebrzeszyn & 0.212 & & & & & Frampol & 0.032 & & \\
\hline Tereszpol & 0.212 & & & & & Sułów & 0.026 & & \\
\hline Goraj & 0.188 & & & & & Biłgoraj & 0.010 & & \\
\hline & & & & & & Zamość & 0.009 & & \\
\hline & & & & & & Turobin & 0.001 & & \\
\hline
\end{tabular}

The value of the potential in the Józefów commune is determined by both the resources and the products. The product is related primarily to Miocene organodetrital limestones in Józefów quarry (Table 7). A similar association is evident in the communes of Krasnobród (Maastrichtian opokas in Krasnobród quarry), Susiec (the steep rapids in the riverbeds), and Lubycza Królewska (fragments of Miocene petrified wood), whereas in other areas the product is related with landscape features determined by geology (loess gullies in Szczebrzeszyn and Goraj communes, residual hills and groups of rocks in Tereszpol).

Table 7. Resources and products with very high geotourism potential (TIGP > 0.184) in the communes.

\begin{tabular}{|c|c|c|}
\hline Communes & Resources & Product \\
\hline Józefów & $\begin{array}{l}\text { Late Cretaceous gaizes (Maastrichtian) } \\
\text { exhibiting dinosaur tracks } \\
\text { (Macropodosaurus sp., cf. Saurexallopus, } \\
\text { and Velociraptorichnus sp. [77] on } \\
\text { Młynarka Hill, } \\
\text { Miocene organodetrital limestones in } \\
\text { the Józefów quarry with scallop, oyster } \\
\text { fossils, traces of foraging organisms, } \\
\text { interesting sedimentary structures (e.g., } \\
\text { a submarine landslide), tectonic } \\
\text { structures [36,78,79], } \\
\text { residual hills over } 340 \text { m a.s.l. (e.g., } \\
\text { "Piekiełko" rock with the peak protected } \\
\text { as a nature monument, Hołda, } \\
\text { Młynarka), } \\
\text { "szypoty" steep rapids in the } \\
\text { Campanian gaizes of the Szum River } \\
\text { riverbed [46]. }\end{array}$ & $\begin{array}{l}\text { - } \quad \text { two museums: Adam Grochowicz } \\
\text { Museum of Masonry, the Geotouristic } \\
\text { Pavilion, } \\
\text { - } \quad \text { thematic Central Roztocze Geotourism } \\
\text { Trail (an abandoned quarry of Miocene } \\
\text { sandstone and coquina beds in } \\
\text { Szopowe, the active "Babia dolina" } \\
\text { quarry of Miocene organodetrital } \\
\text { limestones with an limestone } \\
\text { watchtower in Józefów, a masonry } \\
\text { workshop in Majdan Nepryski), } \\
\text { many hiking and cycling trails, } \\
\text { educational trails (e.g., the "Hotda Hill" } \\
\text { - } \\
\text { trail) includes residual hills as } \\
\text { viewpoints, } \\
\text { cyclical events (Ecological Culture } \\
\text { Festival), } \\
\text { painting and sculpture workshops } \\
\text { based on the resources of the "Babia } \\
\text { dolina" quarry in Józefów and the steep } \\
\text { rapids in the Szum riverbed. }\end{array}$ \\
\hline
\end{tabular}


Table 7. Cont.

\begin{tabular}{|c|c|c|}
\hline Communes & Resources & Product \\
\hline Krasnobród & $\begin{array}{l}\text { Maastrichtian opokas and marly opokas } \\
\text { (carbonate-siliceous rocks) with fossils } \\
\text { of echinoids, ammonites, sponges, and } \\
\text { imprints of coniferous Cunninghamia } \\
\text { and Geinitzia and deciduous Debeya } \\
\text { paulinae trees [40,41] in Krasnobród } \\
\text { quarry, } \\
\text { spring niches in Maastrichtian rocks } \\
\text { supplying water to the Wieprz River in } \\
\text { Krasnobród and Hutki, } \\
\text { Miocene limestone adits in Senderki, } \\
\text { loess outcrops and loess gullies, } \\
\text { Wieprz River valley. }\end{array}$ & $\begin{array}{l}\text { - } \quad \text { the Museum of Krasnobród Village and the } \\
\text { Geological-Pottery Museum in } \\
\text { Krasnobród with a collection of Late } \\
\text { Cretaceous opokas (carbonate-siliceous } \\
\text { rocks) mainly from Krasnobród quarry, } \\
\text { the Central Roztocze Geotourism Trail } \\
\text { running through the Maastrichtian } \\
\text { opoka quarry and Miocene limestone } \\
\text { adits in Senderki, } \\
\text { Krasnobrodzkie Gullies, } \\
\text { - } \quad \text { hiking trail along one of the gullies. }\end{array}$ \\
\hline Susiec & $\begin{array}{l}\text { steep rapids in the riverbeds of the } \\
\text { Sopot in Nowiny village and between } \\
\text { Nowiny and Hamernia and in the } \\
\text { Tanew, Jelen, and Potok Łosiniecki } \\
\text { Rivers near Rybnica (all in } \\
\text { Campanian gaizes), } \\
\text { sand outcrops in the dunes [46]. }\end{array}$ & $\begin{array}{l}\text { - } \quad \text { hiking and cycling trails: the Szlak } \\
\text { "Szumów" Trail, the thematic Central } \\
\text { Roztocze Geotourism Trail running } \\
\text { through the Miocene organodetrital } \\
\text { limestone quarry in Nowiny and the } \\
\text { Sopot and Tanew valleys with steep } \\
\text { rapids in their beds, } \\
\text { educational trails in the Sopot valley, i.e., } \\
\text { the "Czartowe Pole" Reserve Hiking Trail } \\
\text { and the "Czartowe Pole" Nature-Didactic } \\
\text { Trail }[55,58] \text {. }\end{array}$ \\
\hline $\begin{array}{l}\text { Lubycza } \\
\text { Królewska }\end{array}$ & $\begin{array}{l}\text { fragments of petrified wood of Miocene } \\
\text { Taxodioxylon taxodii from the family } \\
\text { Cupressaceae [37]. }\end{array}$ & $\begin{array}{l}\text { - the Culture and Nature "Trail of Petrified } \\
\text { Trees" in Siedliska with the exhibition of } \\
\text { fragments of silicified wood in the } \\
\text { Museum of Petrified Trees, a small grove } \\
\text { with swamp cypress trees, the Prutnik } \\
\text { River spring with pulsating fountains. }\end{array}$ \\
\hline $\begin{array}{r}\text { Szczebrzeszyn } \\
-\end{array}$ & $\begin{array}{l}\text { Maastrichtian opokas and marly opokas } \\
\text { containing numerous fossils, e.g., } \\
\text { Belemnitella junior Nowak, Belemnella } \\
\text { kazimiroviensis, Hoploscaphites } \\
\text { constrictus [42]. } \\
\text { loess outcrops, loess gullies, } \\
\text { wide Wieprz River valley with } \\
\text { meanders, } \\
\text { thick (10-15) loess cover dissecting the } \\
\text { system of gullies with the highest } \\
\text { average density in Roztocze [49]. }\end{array}$ & 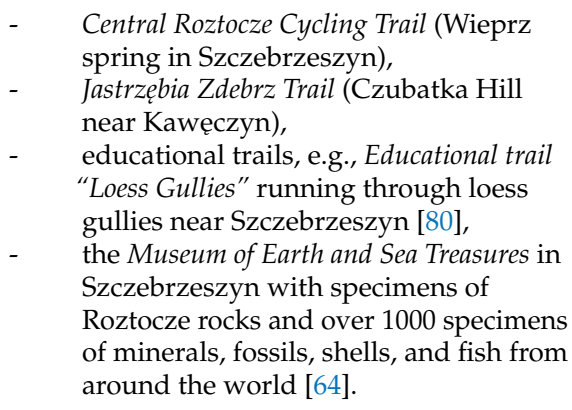 \\
\hline Tereszpol & $\begin{array}{l}\text { disused Maastrichtian gaize quarries in } \\
\text { Li-powiec, } \\
\text { Miocene marly and detritic limestones } \\
\text { in Żelebsko, } \\
\text { geosites with petrified wood [45], } \\
\text { residual hills (e.g., Kamienna, Wysoka, } \\
\text { and Michałowa), } \\
\text { rocks and groups of rocks (e.g., on the } \\
\text { northern slope of Lasowa Góra). }\end{array}$ & $\begin{array}{l}\text { the Central Roztocze Cycling Trail, which } \\
\text { leads e.g., to Lasowa Góra and rocks } \\
\text { exposed on its slope. }\end{array}$ \\
\hline
\end{tabular}


Table 7. Cont.

\begin{tabular}{|c|c|c|}
\hline Communes & Resources & Product \\
\hline Goraj & $\begin{array}{l}\text { abandoned quarries of Maastrichtian } \\
\text { marly opoka rocks [42] and Miocene } \\
\text { marly and detritic limestones [36], } \\
\text { residual hills (e.g., Wielka Jeżówka, } \\
\text { Grabowa Góra, Góra Chełmik) with } \\
\text { altitudes of approx. } 330 \text { m a.s.l., } \\
\text { Biała Łada valley, } \\
\text { rock shelters (caves) in Maastrichtian } \\
\text { opokas (so-called Gorajskie Skały) and } \\
\text { in Miocene limestones on Góra } \\
\text { Chełmik [81]. }\end{array}$ & $\begin{array}{l}\text { - } \quad \text { the Central Roztocze Cycling Trail along } \\
\text { the Biała Łada valley, } \\
\text { - } \quad \text { the Jastrzębia Zdebrz Trail on the hills of } \\
\text { Wielka Jeżówka and Grabowa Góra [80], } \\
\text { - } \quad \text { the cyclical nationwide "Jastrzebia } \\
\text { Zdebrz" cycling rally [82] with the route } \\
\text { leading on the hills mentioned above. }\end{array}$ \\
\hline
\end{tabular}

The potential of Krasnobród commune is influenced by diversified resources.

Horyniec-Zdrój and Zwierzyniec represent communes with a high geotourism potential (TIGP $=0.123-0.183$ ) (Table 5). Both these areas are characterized by large differences in terms of values and geotourism products. The Miocene limestone-sandstone rocks with related relief forms and parameters of the waters are the main resources in the HoryniecZdrój commune, whereas products associated with the Roztocze National Park are the major products in Zwierzyniec commune (Table 8).

Table 8. Resources and products with high geotourism potential (TIGP $=0.123-0.183$ ) in the communes.

\begin{tabular}{|c|c|c|}
\hline Communes & Resources & Product \\
\hline Horyniec-Zdrój & $\begin{array}{l}\text { - } \quad \text { outcrops of Miocene limestones and sandstones, } \\
\text { Miocene limestone-sandstone rocks (Diabelski } \\
\text { Kamien, Diabelskie Kamienie, "Kopiec } \\
\text { termitów"), } \\
\text { caves (Jaskinia Diabelska, Jaskinia w } \\
\text { Niedźwiedziach) with limestone-sand } \\
\text { "deposits", } \\
\text { - } \quad \text { ravines (Łówczanka, Dublen, and Sopot Mały } \\
\text { Rivers) formed in Miocene limestones and } \\
\text { sandstones, } \\
\text { steep rapids formed in Campanian gaizes in } \\
\text { these ravines [46], } \\
\text { - Świdnica spring [45], } \\
\text { - } \quad \text { mineral sulfide waters and peat bogs [83], i.e., } \\
\text { the basis for the functioning of the health resort } \\
\text { in Horyniec-Zdrój. }\end{array}$ & $\begin{array}{l}\text { - } \quad \text { educational trail: Horyniec-Zdrój-Nowiny } \\
\text { Horynieckie Trail (the Świdnica spring). }\end{array}$ \\
\hline Zwierzyniec & 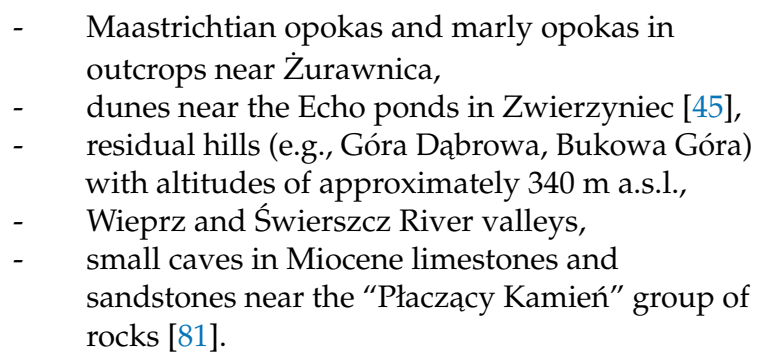 & $\begin{array}{l}\text { - } \quad \text { nature collections in the Educational Center } \\
\text { and Museum of the Roztocze National Park, } \\
\text { - } \quad \text { educational trails, e.g., the Educational Trail } \\
\text { to Bukowa Góra, the Educational trail along } \\
\text { the dune to the "Echo" ponds [53], } \\
\text { - } \text { the Central Roztocze Cycling Trail along the } \\
\text { Wieprz spring in Wywłoczka and the } \\
\text { "Echo" pond dunes [80]. }\end{array}$ \\
\hline
\end{tabular}

A moderate value of the geotourism potential (TIGP $=0.061-0.122)$ was determined in the case of Chrzanów, Radecznica, and Adamów communes (Table 6). In total, two of these areas (Chrzanów and Radecznica communes) are characterized by landscape values associated with loess gullies as well as numerous carbonate water springs, with which the 
product is associated. In turn, interesting resources of Maastrichtian rock in the quarry in

Bliżów (Adamów commune) are practically not used (Table 9).

Table 9. Resources and products with moderate geotourism potential (TIGP $=0.061-0.122$ ) in the communes.

\begin{tabular}{|c|c|c|}
\hline Communes & Resources & Product \\
\hline Chrzanów & outcrops of Maastrichtian marly opokas near Chrzanów [42]. & $\begin{array}{l}\text { - } \quad \text { the Central Roztocze Cycling Trail [80] } \\
\text { across the Biała Łada valley. }\end{array}$ \\
\hline Radecznica & $\begin{array}{l}\text { - } \quad \text { gullies formed in the loess cover, } \\
\text { springs, in particular the group of the Por springs in Zaporze, } \\
\text { which are the most efficient (approximately } 300 \mathrm{dm}^{3} \bullet \mathrm{s}^{-1} \text { ) [84] } \\
\text { in the analyzed area, } \\
\text { - } \quad \text { springs in Radecznica, } \\
\text { - Gorajec River springs in Trzęsiny. }\end{array}$ & $\begin{array}{l}\text { - } \quad \text { the Central Roztocze Cycling Trail } \\
\text { running along the Por springs in } \\
\text { Radecznica and the Dzielce loess gully } \\
\text { [80]. }\end{array}$ \\
\hline Adamów & $\begin{array}{l}\text { - Maastrichtian opoka and marl with shells, imprints, and molds } \\
\text { of mollusk macrofauna [45] in the quarry in Bliżów. }\end{array}$ & - $\quad$ hiking tours. \\
\hline
\end{tabular}

In total, 9 of the 22 analyzed communes have a low geotourism potential (TIGP = 0.001-0.060) (Table 6). It is characteristic that only in two communes-Narol and Tomaszów Lubelski-the geotourist product refers to some resources, while there is no product based on the diversified geotouristic resources in as many as four communes (Bełżec, Biłgoraj, Krynice, Zamość communes). In three communes (Frampol, Sułów, Turobin), there is only one product related to the features of the loess landscape (Table 10).

Table 10. Resources and products with low geotourism potential (TIGP $=0.001-0.060)$ in the communes.

\begin{tabular}{|c|c|c|}
\hline Communes & Resources & Product \\
\hline Narol & $\begin{array}{l}\text { - } \quad \text { Lówcza River valley with small rapids in } \\
\text { Campanian gaizes [46], } \\
\text { - } \quad \text { Tanew Valley and its springs in Wola Wielka, } \\
\text { - } \quad \text { Różaniec River spring, } \\
\text { - Wielki Dział-one of the highest hills in the } \\
\text { analyzed area. }\end{array}$ & $\begin{array}{l}\text { - } \quad \text { the Szlak im. św. Brata Alberta trail leading to Wielki Dział, } \\
\text { and rallies organized periodically associated with it, } \\
\text { - } \quad \text { cyclical event, i.e., the Green Velo Bicycle Rally, runs through } \\
\text { Wielki Dział and the Eówcza River valley [58]. }\end{array}$ \\
\hline Tomaszów Lubelski & 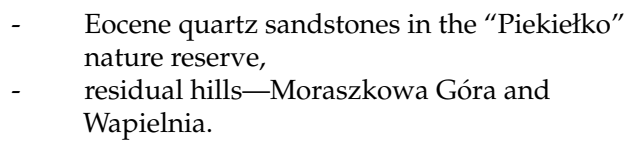 & $\begin{array}{l}\text { tourist trails: Central Roztocze Geotourism Trail, Władysława } \\
\text { Podobińska Trail (Wapielnia), Historical Trail ("Piekiełko"). }\end{array}$ \\
\hline Frampol & $\begin{array}{l}\text { - } \quad \text { outcrops of Miocene reef limestones on } \\
\text { Łamana and Łysiec hills [36], } \\
\text { gullies and dry denudation valleys near } \\
\text { Komodzianka. }\end{array}$ & $\begin{array}{ll}\text { - } & \text { the Zdebrz Jastrzębia Trail, } \\
\text { - } & \text { events (hiking rallies): the National Roztocze Rally "Jastrzębia }\end{array}$ \\
\hline Sułów & - $\quad$ gullies and loess outcrops in Sąsiadka. & $\begin{array}{l}\text { Zdebrz" (gullies near Komodzianka), the "Meet the Spring" } \\
\text { Rally (loess outcrops in Sasiadka) [58,82]. }\end{array}$ \\
\hline Turobin & $\begin{array}{l}\text { - } \quad \text { gullies in the loess cover [49], } \\
\text { - } \quad \text { outcrops of Maastrichtian opokas and marly } \\
\text { opokas [85]. }\end{array}$ & \\
\hline
\end{tabular}


Table 10. Cont.

\begin{tabular}{cll}
\hline Communes & \multicolumn{1}{c}{ Resources } \\
\hline Bełżec & - & $\begin{array}{l}\text { Putcrops of aeolian sands in dunes, } \\
\text { small spring niches. }\end{array}$ \\
\hline Biłgoraj & - & $\begin{array}{l}\text { Miocene reef limestones in Dyle and Żelebsko } \\
\text { outcrops, } \\
\text { dunes near Ignatówka [45]. }\end{array}$ \\
\hline Krynice & - & $\begin{array}{l}\text { Kryniczanka valley, } \\
\text { network of gullies eroded in the loess cover. }\end{array}$ \\
\hline Zamość & - & hilly landscape. \\
\hline
\end{tabular}

The comparison of the values of total indices calculated for both spheres of the geotourism potential, i.e., resources and products, shows the highest values of resources in two municipalities: Tereszpol (0.203) and Józefów (0.189). In both areas, the highest $(0.133$ and 0.130 , respectively) proportion is represented by disused and active quarries. In turn, the Horyniec-Zdrój commune is distinguished for its diversity of landforms (0.098).

In terms of the geotourism product, the highest total index value was achieved by Józefów commune (0.268), with the largest proportion (0.128) of linear products, especially cycling routes and educational trails. In turn, Zwierzyniec commune has the highest score in the section of museum exhibitions of abiotic nature collections (0.052).

\subsection{Diversity of the Geotourism Function Based on the Number of Users of Resources and Products}

The geotourism function of each commune was analyzed based on the Total Geotourism Function Index (TGFI) taking into account the number of tourists visiting the resources and products.

Four communes: Krasnobród, Józefów, Zwierzyniec, and Lubycza Królewska were indicated as areas with a very well developed (TGFI > 0.184) geotourism function (Table 11)

Table 11. Diversity of the geotourism function of communes located within the Roztocze TBR shown by the Total Geotourism Function Index, TGFI.

\begin{tabular}{|c|c|c|c|c|c|c|c|c|c|}
\hline \multicolumn{10}{|c|}{ Geotourism Function } \\
\hline \multicolumn{2}{|c|}{ Very Well Developed } & \multicolumn{2}{|c|}{ Well Developed } & \multicolumn{2}{|c|}{ Moderately Developed } & \multicolumn{2}{|c|}{ Poorly Developed } & \multicolumn{2}{|c|}{ Not Developed } \\
\hline Communes & $\begin{array}{c}\text { TIGP> } \\
0.184\end{array}$ & Communes & $\begin{array}{c}\text { TIGP0.123- } \\
0.183\end{array}$ & Communes & $\begin{array}{c}\text { TIGP0.061- } \\
0.122\end{array}$ & Communes & $\begin{array}{c}\text { TIGP0.001- } \\
0.060\end{array}$ & Communes & $\begin{array}{l}\text { TIGP } \\
0.000\end{array}$ \\
\hline \multirow{2}{*}{$\begin{array}{l}\text { Krasnobród } \\
\text { Józefów }\end{array}$} & 0.284 & Susiec & 0.179 & Adamów & 0.111 & Narol & 0.039 & Bełżec & 0.000 \\
\hline & 0.255 & & & Goraj & 0.090 & Szczebrzeszyn & 0.033 & Krynice & 0.000 \\
\hline Zwierzyniec & 0.220 & & & Frampol & 0.066 & Horyniec-Zdrój & 0.032 & Biłgoraj & 0.000 \\
\hline \multirow{5}{*}{$\begin{array}{l}\text { Lubycza } \\
\text { Królewska }\end{array}$} & 0.211 & & & Tomaszów & 0.061 & Sułów & 0.029 & Zamość & 0.000 \\
\hline & & & & Lubelski & & & & & \\
\hline & & & & & & Tereszpol & 0.027 & Turobin & 0.000 \\
\hline & & & & & & Radecznica & 0.010 & Tarnawatka & 0.000 \\
\hline & & & & & & Chrzanów & 0.008 & & \\
\hline
\end{tabular}

The very well-developed tourist function in the Krasnobród commune is associated with events related to the resources (Maastrichtian opokas in Krasnobród quarry), likewise in Józefów commune (Miocene organodetrital limestones in Józefów quarry) (Table 12). The geotouristic function is associated with visitors to the Museum of Petrified Trees in Siedliska in Lubycza Królewska commune and visitors to the Roztocze National Park in Zwierzyniec commune. 
Table 12. Communes with a very well-developed (TGFI > 0.184) geotourism function.

\begin{tabular}{|c|c|c|}
\hline Communes & Resources & Product \\
\hline Krasnobród & $\begin{array}{l}\text { disused Maastrichtian marly opoka quarry } \\
\text { with animal and plant fossils-visited by } \\
\text { groups of students and participants of school } \\
\text { trips, and individual tourists who often intend } \\
\text { to visit of the watchtower above the quarry, } \\
\text { springs, i.e., the Belfont, the spring under the } \\
\text { "Chapel on the Water" in Krasnobród (both } \\
\text { recharge the Wieprz River), mainly due to the } \\
\text { characteristics of the groundwater flowing } \\
\text { from Late Cretaceous rocks. }\end{array}$ & $\begin{array}{l}\text { - } \quad \text { the Museum of Krasnobród Village and the } \\
\text { Geological-Pottery Museum in } \\
\text { Krasnobród-visited by school trips, many } \\
\text { students; } \\
\text { - } \quad \text { cycling rallies, e.g., Józefów May Cycling Tour, } \\
\text { - } \quad \text { hiking events such as Along Roztocze Hills, } \\
\text { - } \quad \text { Santa Claus Rally hiking trips [57,58]—with } \\
\text { the Sopot River spring in Husiny and the } \\
\text { adits in Potok Senderki village. }\end{array}$ \\
\hline Józefów & $\begin{array}{l}\text { - the Miocene organodetrital limestone quarry } \\
\text { ("Babia dolina") and the watchtower in } \\
\text { Józefów, } \\
\text { - } \\
\text { the Kamień Hill (“Piekiełko" reserve) near } \\
\text { Stanisławów—by hiking tourists, } \\
\text { - } \quad \text { steep rapids in the Szum nature reserve near } \\
\text { Górecko Kościelne—visited by bicycle tourists. }\end{array}$ & $\begin{array}{l}\text { - cyclical rallies: Golden Autumn in Roztocze } \\
\text { with Radio Lublin, Józefów May Cycling Tour, } \\
\text { "EKOrajd", } \\
\text { - } \quad \text { cycling events and hiking tours, e.g., Along } \\
\text { Roztocze Hills, } \\
\text { - } \quad \text { the "EKOrajd" bicycle event, } \\
\text { - } \quad \text { rallies, e.g., the international cycling rally } \\
\text { along the Central Roztocze Cycling Trail "On } \\
\text { the wings of nature", } \\
\text { - } \quad \text { the Geotouristic Pavilion in Józefów }[57,58] \text {. }\end{array}$ \\
\hline Zwierzyniec & $\begin{array}{l}\text { - } \quad \text { the Wieprz spring in Wywłoczka, } \\
\text { - } \quad \text { the dunes at the "Echo" ponds. }\end{array}$ & $\begin{array}{l}\text { - } \quad \text { Roztocze National Park: the Educational Trail } \\
\text { to Bukowa Góra, the Educational Center and } \\
\text { Museum of the Roztocze National Park, } \\
\text { - } \quad \text { the Central Roztocze Cycling Trail, } \\
\text { - } \quad \text { the Guciów Farm open-air museum. }\end{array}$ \\
\hline Lubycza Królewska & Kragły Goraj hill [58]. & $\begin{array}{l}\text { - the Museum of Petrified Trees in Siedliska-by } \\
\text { school children and teenagers, individual } \\
\text { tourists, hiking groups. }\end{array}$ \\
\hline
\end{tabular}

Susiec commune is characterized by a high value of the total geotourism function index (TGFI $=0.123-0.183$ ) (Table 13). This function is primarily associated with visitors to the steep rapids in the riverbeds of the Sopot and Tanew River valleys.

Table 13. Communes with a high value of the total geotourism function index (TGFI $=0.123-0.183$ ).

\begin{tabular}{|c|c|c|}
\hline Communes & Resources & Product \\
\hline Susiec & $\begin{array}{l}\text { - } \\
\text { and "Napot and Tanew River valleys, i.e., "Czartowe Pole", whose fragments with steep } \\
\text { rapids in the riverbeds are part of a protected } \\
\text { reserve-visited by organized tourist groups and } \\
\text { individual visitors. }\end{array}$ & 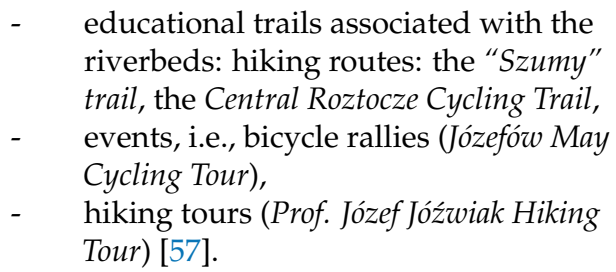 \\
\hline
\end{tabular}

The geotourism function is moderately developed (TGFI $=0.061-0.122$ ) in Adamów, Goraj, Frampol, and Tomaszów Lubelski communes (Table 14). The geotourism function in Goraj and Frampol communes is mainly associated with cyclists participating in the cyclical National Roztocze Rally "Jastrzebia Zdebrz", while individual tourists visiting the opoka quarry in Bliżów and Wapielnia hill are related to the geotourism function in the other communes. 
Table 14. Communes with a moderately developed (TGFI $=0.061-0.122$ ) geotourism function.

\begin{tabular}{|c|c|c|}
\hline Communes & Resources & Product \\
\hline Adamów & $\begin{array}{l}\text { - } \quad \text { the abandoned Maastrichtian opoka quarry } \\
\text { in Bliżów—by individual tourists. }\end{array}$ & $\begin{array}{l}\text { - } \quad \text { hiking tours, e.g., the "Little Red Riding Hood" } \\
\text { Rally irregularly organized [58]. }\end{array}$ \\
\hline Goraj & Wielka Jeżówka and Grabowa Góra hills. & cvclical National Roztocze Rallu "Iastrzehia Zdehrz" \\
\hline Frampol & loess gullies [82]. & \\
\hline $\begin{array}{l}\text { Tomaszów } \\
\text { Lubelski }\end{array}$ & - Wapielnia hill. & $\begin{array}{l}\text { - } \quad \text { the Central Roztocze Geotourism Trail to Wapielnia } \\
\text { hill—by individual tourists. }\end{array}$ \\
\hline
\end{tabular}

The geotourism function is poorly developed (TGFI $=0.001-0.060$ ) in seven communes and not developed (TGFI $=0.000$ ) in six (Table 7). In the group of communes with a poorly developed geotourism function, attention should be paid to Horyniec-Zdrój, where only some of the many resources are visited, mainly by sanatorium patients (Table 15). The landscape assests (hills, valleys) are the most popular among tourists in Narol and Tereszpol communes, likewise in Szczebrzeszyn and Sułów communes (loess gullies).

Table 15. Communes with a poorly developed $(\mathrm{TGFI}=0.001-0.060)$ geotourism function .

\begin{tabular}{|c|c|c|}
\hline Communes & Resources & Product \\
\hline Narol & $\begin{array}{ll}\text { - } & \text { Wielki Dział—visited by cyclists, } \\
\text { - } & \text { Łówcza River valley, } \\
\text { - } & \text { Różaniec River spring. }\end{array}$ & $\begin{array}{l}\text { - } \quad \text { the Roztocze Green Velo Bicycle Rally-visited by the } \\
\text { number of participants. }\end{array}$ \\
\hline Szczebrzeszyn & $\begin{array}{l}\text { - Wieprz River spring-visited by } \\
\text { groups of schoolchildren, } \\
\text { - } \quad \text { loess gullies—visited by students. }\end{array}$ & $\begin{array}{l}\text { - } \quad \text { routes leading to the Wieprz River spring with the } \\
\text { "Beetle" monument and to the "Piekiełko" loess } \\
\text { gullies [87]—visited by individual tourists. }\end{array}$ \\
\hline Horyniec-Zdrój & $\begin{array}{l}\text { - Długi Goraj-the highest hill in the } \\
\text { analyzed area. }\end{array}$ & $\begin{array}{l}\text { - } \quad \text { the educational Horyniec-Zdrój-Nowiny Horynieckie } \\
\text { Trail leading to the Świdnica River spring in Nowiny } \\
\text { Horynieckie [88] visited by mainly sanatorium } \\
\text { patients, } \\
\text { - the "Roztocze Lovers" Rally event [58]. }\end{array}$ \\
\hline Sułów & loess outcrops in Sąsiadka [58]. & - $\quad$ the Meet the Spring" Rally. \\
\hline Tereszpol & $\begin{array}{l}\text { - geosites, e.g., Lasowa Góra and } \\
\text { rocks exposed on its slope. }\end{array}$ & \\
\hline Radecznica & Por River spring in Radecznica. & - $\quad$ the Central Roztocze Cycling Trail_-by cycling tourists. \\
\hline Chrzanów & Biała Łada valley. & \\
\hline
\end{tabular}

The comparison of the values of total indices calculated for both function spheres, i.e., resources and products, shows that the highest values of the resource-based function were obtained for Lubycza Królewska (0.104) and Adamów (0.100) communes. In both areas, the highest index ( 0.100 in each) was calculated for visits to the disused and active quarries. In turn, Susiec commune had the highest index (0.071) in terms of tourist visits to landforms. In terms of the exploitation of the geotourism product, the highest total index was achieved by Zwierzyniec commune (0.220), with the highest proportion $(0.128)$ of visitors to the museum exhibitions of abiotic nature collections (0.120). 


\section{Discussion}

\subsection{Relationships between the Geotourism Potential and Function}

The comparative analysis of the values of the total indicator of geotourism potential and the total geotourism function index showed a variety of their mutual relationships (Figure 9).

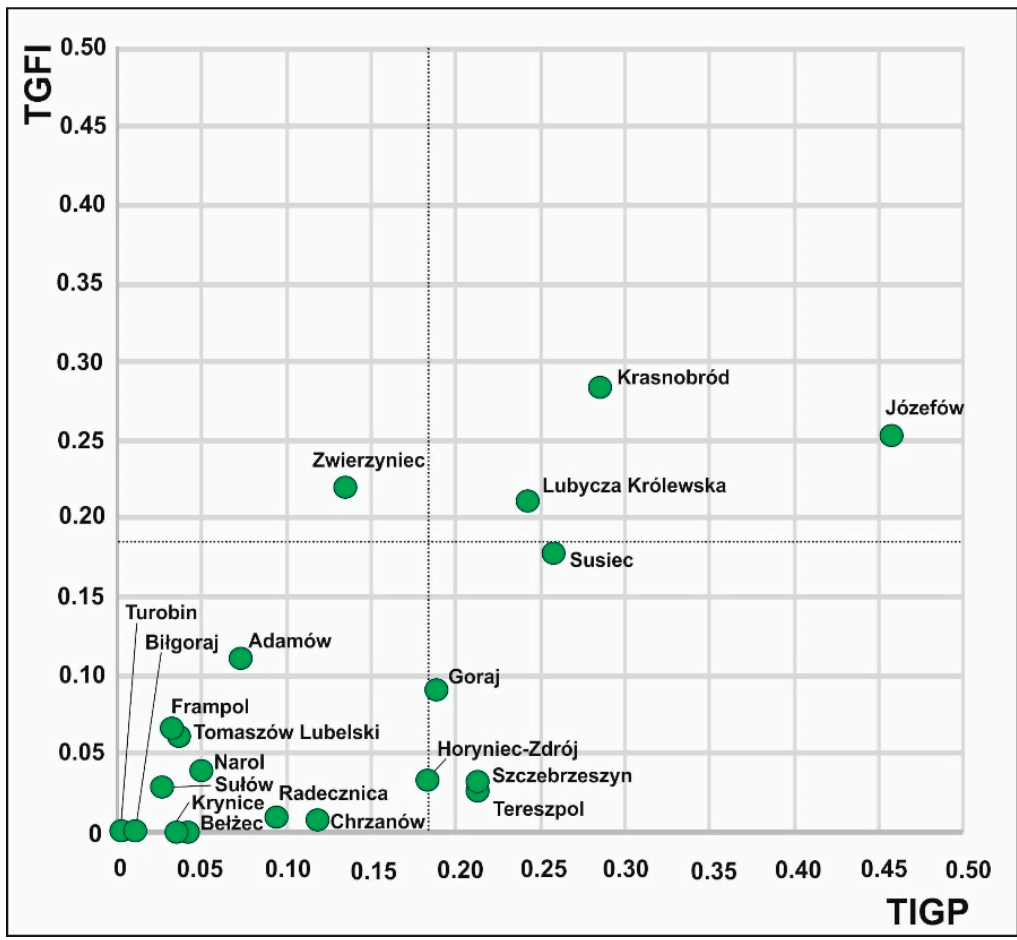

Figure 9. Location of the Roztocze TBR communes in the two-dimensional space of the total indicator of geotourism potential (TIGP) and the total geotourism function index (TGFI).

The current geotourism potential turned out to be the most intensively used only in the Krasnobród commune (Figure 9). It should be emphasized, however, that a substantial number of tourists exploit the resources not only for educational but also health (Belfont spring) or religious (Wieprz spring at the "Chapel on the Water" in Krasnobród) purposes. Similarly, in the case of individual trips to the disused quarry, greater interest than the rocks and fossils is aroused by the watchtower and the possibility to admire the panorama of the Wieprz valley (also through a telescope). The landscape assets attract artists who intend to paint the views.

Lubycza Królewska commune is another area where the geotourism potential is largely exploited (Figure 9). This is associated with the number of visitors to both the resources, i.e., the fragments of petrified wood of Miocene plants from the family Cupressaceae, and the related product. However, the group of visitors comprises a large number of those who visit the Prutnik River spring for the health-related properties of its water, i.e., indirect geotourism assets.

Undoubtedly, Józefów commune is an area with the greatest geotourism potential (Figure 9). However, the comparison of the calculated values of the indices indicates that neither the resources nor the related products are being fully used. Therefore, certain steps have to be taken to achieve balance between the potential and the function.

Susiec, Szczebrzeszyn, Tereszpol, and Goraj communes are areas with a relatively high potential in relation to the function (Figure 9).

Noteworthy is the relationship between the geotourism potential and function in the Zwierzyniec commune (Figure 9). The function here appears to be excessively developed in relation to the resources, which suggests that the area is overloaded by tourist movement. 
Therefore, some measures are advisable to be taken in order to disperse/shift tourists to another area, especially in the spring and autumn seasons.

The values of the indices show that the tourist movement in most communes covered by the Roztocze TBR is concentrated around resources that have become tourist attractions, e.g., the steep rapids in the Sopot, Tanew, and Jelen rivers. A majority of products associated with the wide spectrum of geotourism resources are linear, and their marketing message encourages tourists to spend time actively (cycling trails and hiking rallies) rather than exploit the educational aspect related to geology. Only one linear product, i.e., the Szlak Szumów trail, conveys a message related to the Earth heritage in its name.

It should also be emphasized that the function is associated with the geotourism product in only a few of the 22 analyzed communes; in fact, only the Museum of Petrified Trees in Siedliska refers to the geological heritage of the area in its marketing message.

The comparison of the geotourist potential (TIGP) values obtained in the analyzed communes with the published values of the total potential [28] shows that Lubycza Królewska, Józefów, and Susiec communes have the highest contribution to the geotourism potential within the total potential (Figure 10). In turn, the comparison of the respective sizes of functions (Figure 11) indicates the highest contribution to the general geotourism function only in the Józefów commune. However, the results of these comparisons should not be treated arbitrarily, as both the potential and function change over time due to the expansion of the product offer and changes in the volume of tourist traffic.

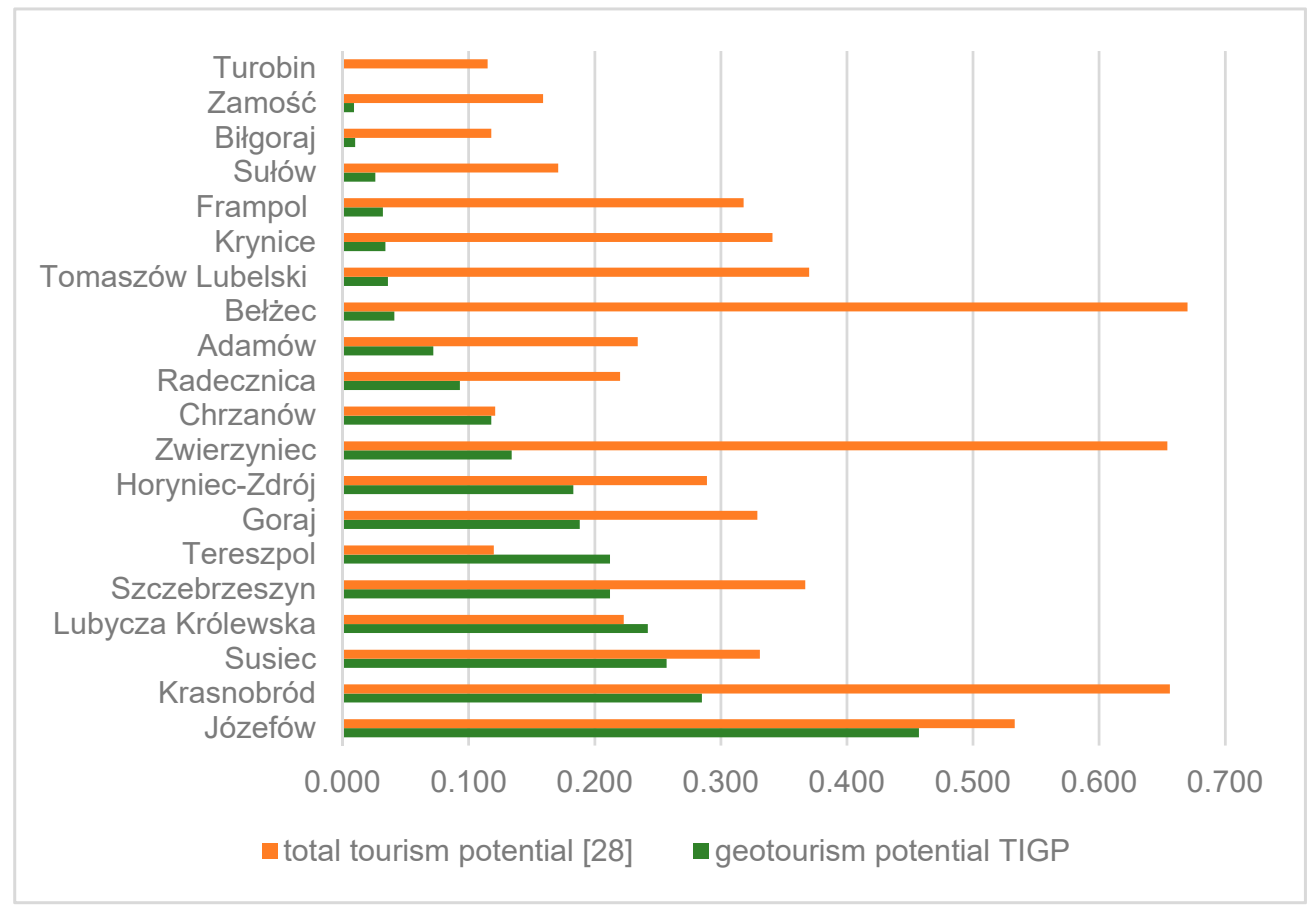

Figure 10. Comparison of the geotourism potential (TIGP) in the analyzed communes with the values of the total tourism potential [28]. 


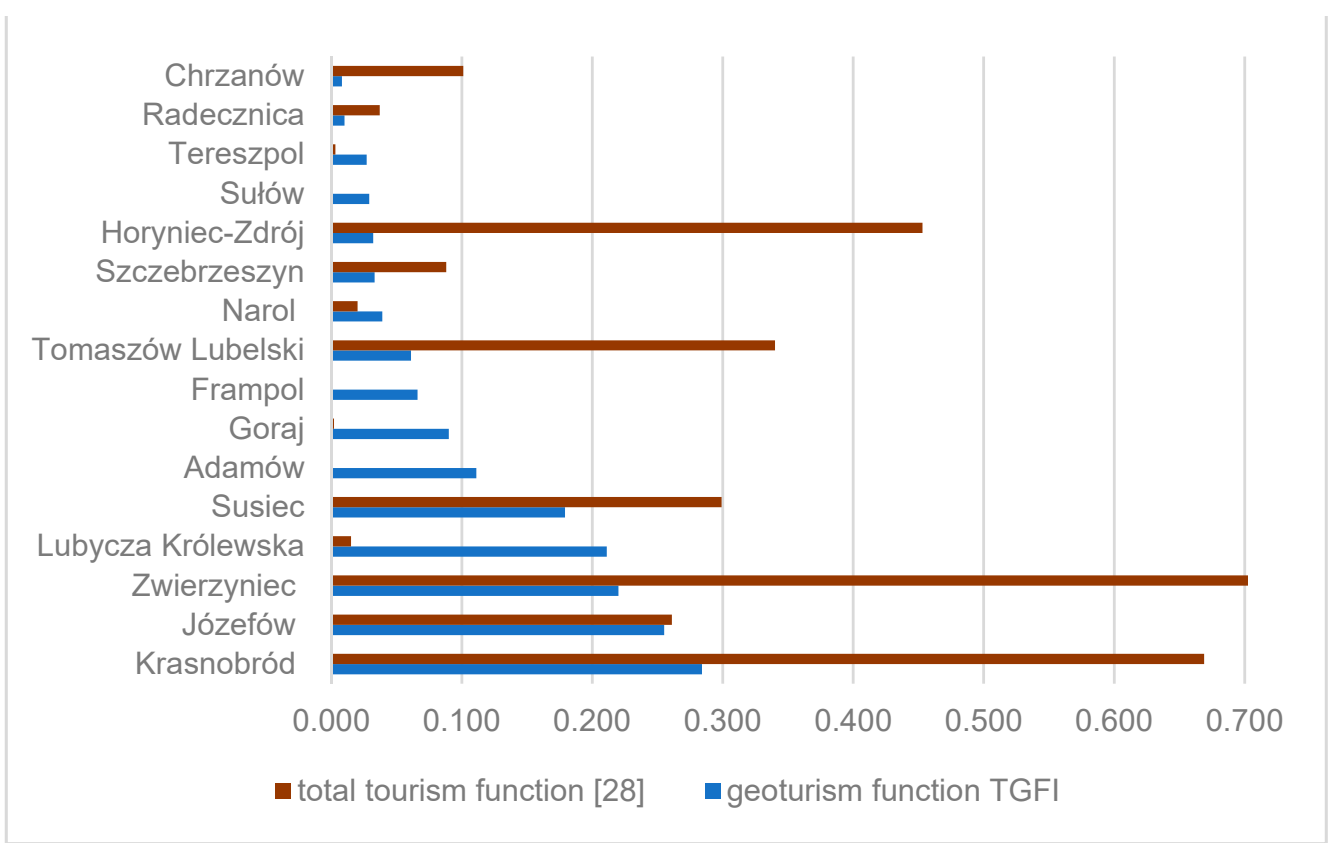

Figure 11. Comparison of the geotourism function (TGFI) in the analyzed communes with the values of the overall tourism function [28].

4.2. Assessment of the Possibility of Employing the Geotourism Potential of the Roztocze TBR for Establishment the "Kamienny Las na Roztoczu" Geopark

The comparison of the values of the total indicator of geotourism potential TIGP and the total geotourism function index TGFI calculated for the analyzed communes indicates that Józefów, Krasnobród, Susiec, and Lubycza Królewska communes have the greatest possibilities of exploitation of the Roztocze TBR potential with the prospect of the establishment of the "Kamienny las na Roztoczu" geopark. The communes already have some geotourism products, e.g., the Central Roztocze Geotourism Trail (Figure 12) running through the area of the first three communes, the Geotouristic Pavilion in Józefów, and the Museum of Petrified Trees in Siedliska in Lubycza Królewska commune. The products should be associated with education, interpretation, and promotion of geotourism resources in accordance with the definition of geotourism proposed by T. Hose [89], i.e., its didactic function and interpretation of resources as the principal task.

Currently, Józefów commune has been found to have the greatest opportunities for the development of an educational geotourism product. This is connected with the Central Roztocze Geotourism Trail leading from the Geotouristic Pavilion through the "Babia dolina" quarry of Miocene organodetrital limestones in Józefów to the masonry workshop in Majdan Nepryski. The offer should be enriched by the organization of cyclical workshops teaching children and teenagers to make small objects from organodetrital limestone. This is especially important, as the stonework traditions in Józefów are continued [90]. The Geotouristic Pavilion (Figure 12c) could be a convenient facility for the workshops, and the collections of tools used in limestone mining and processing and the numerous sculptures made of Miocene organodetrital limestone could serve as the basis of the activity. Additionally, "identification of fossils in Miocene rocks" workshops should be organized in the quarry. Another option is classes for children in making imprints of identified fossils in salt mass or in shortcrust pastry that can later be baked in a nearby bakery. 

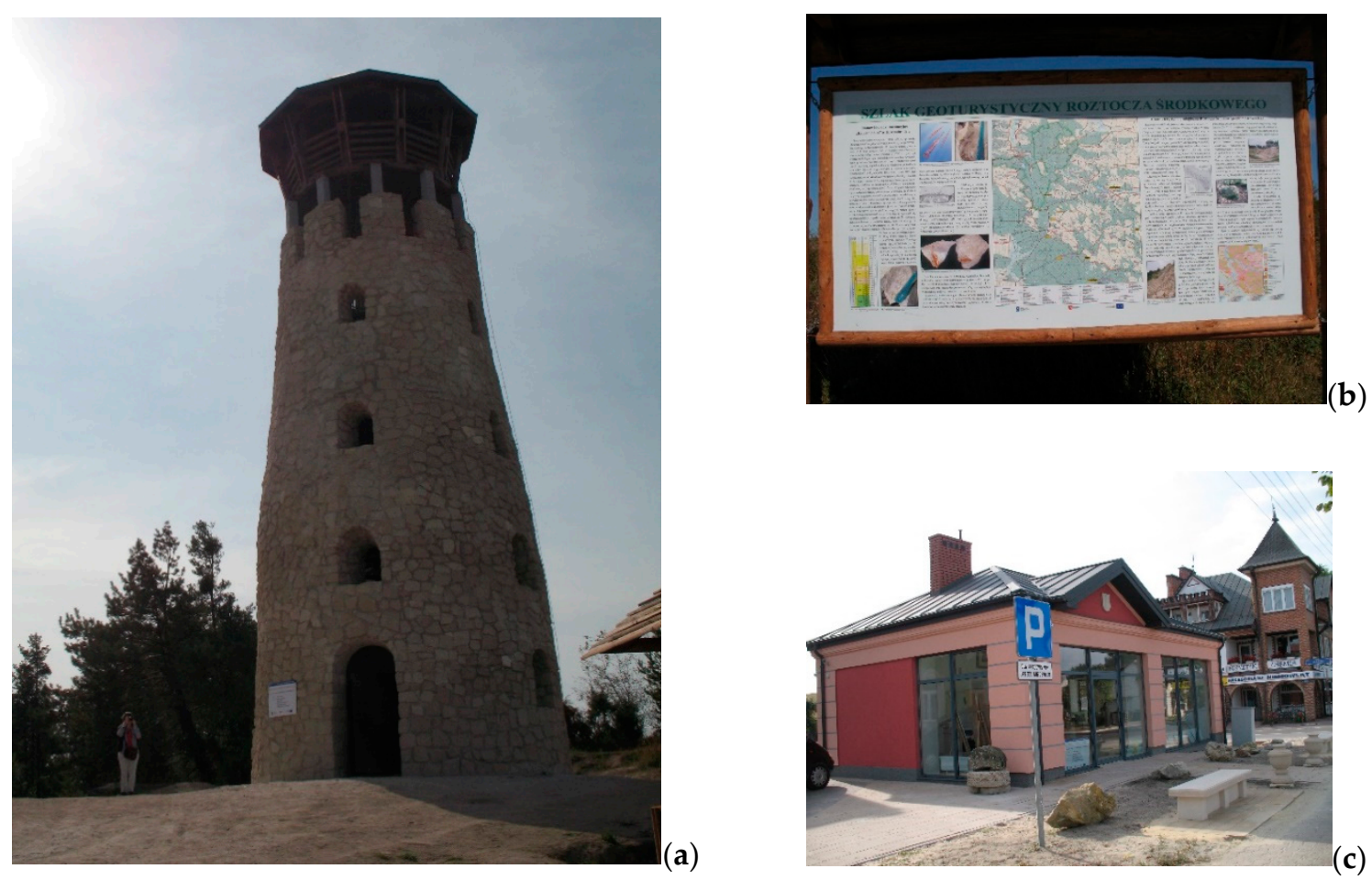

Figure 12. Some objects on the Central Roztocze Geotourism Trail: (a) limestone watchtower in Józefów, (b) one of the charts, (c) Geotouristic Pavilion.

In total, two communes, Józefów and Krasnobród, have a high potential of the preparation of a common educational geoproduct with the prospect of establishment the geopark. This could be inspired by the presence of tracks of herbivorous duck-billed dinosaurs (hadrosaurs) in the Maastrichtian gaizes in Potok Senderki and bear-like footprints of Macropodosarus [77] on Góra Młynarka. The Geotouristic Pavilion in Józefów could serve as an art studio for organizing these workshops.

Moreover, the potential for designing an educational offer in the Krasnobród commune is associated with the presence of imprints of coniferous Cunninghamia and Geinitzia and deciduous Debeya trees [40,41] in the abandoned Maastrichtian opoka quarry in Krasnobród. With reference to the tracks mentioned above, the title of the workshop could be "What did Upper Cretaceous herbivorous dinosaurs eat?" Another resource in Krasnobród commune is the disused Miocene calcareous sandstone underground quarry (adits), formerly used for production of e.g., millstones and grindstones in Senderki. The adits, however, require adequate protection and a display facility. The agritourism facilities in the village offer the possibility of organization of e.g., "From the Miocene sandstone to the millstone" workshops.

The collection of approximately 500 petrified fragments of Miocene swamp cypress trees in the Museum of Petrified Trees in Siedliska (Lubycza Królewska commune) could be enriched with interesting educational display boards or multisensory panels and, with the youngest geotourists in mind, workshops and/or art competitions on "How is wood petrified?" could be designed.

In terms of interpretation and promotion and in the context of the proposed geopark, the potential in the aforementioned communes, i.e., the Late Cretaceous fossils in Krasnobród and the Miocene fossil clams and scallops in Józefów, is worth popularizing in simple products, e.g., folk handicraft products such as tapestries, napkins, Easter eggs, and other items manufactured by local craftsmen.

As in other areas, the analyzed geotourism potential can be popularized through food products, e.g., ammonite-shaped cakes or d inosaur paw-shaped waffles in Krasnobród, cakes in the shape of Miocene scallops or shells (Lima) in Szopowe, and "rhodoid" 
dumplings named after the Miocene rhodoid limestones from Józefów. Food geoproducts usually have quite a strong and positive impact on tourists according to the concept of the product echo [91] referring to the phases of consumption and memories associated with the product.

In Józefów commune, there are good grounds for creation of a thematic village in the stone/limestone town of Józefów. The local Miocene organodetrital limestone has long been used in the construction industry (facades, fences, gazebos, wells). There are also many elements of the so-called small architecture, especially in the market square (sundial, pillory, flower beds) and near the new water reservoir.

All these proposed actions should comply with the principles of sustainable development of the area $[22,23]$. They should aim at protection of the resources by e.g., encouraging the residents to produce fossil casts instead of selling natural ones [14,15], integration of traditional products with geotourism resources with a view to interpretation thereof, and supporting the development of the local economy through generating additional income by the local population or attracting private capital [25-27].

\section{Conclusions}

The comparison of the values of the total indicator of geotourism potential TIGP and the total geotourism function index TGFI calculated for the 22 communes covered by the Roztocze TBR indicates that the potential is reflected in the development of the function only in two communes: Krasnobród and Lubycza Królewska. However, it should be emphasized that a substantial number of tourists in both communes exploit the geotourism resources for health and/or religious reasons.

Undoubtedly, Józefów commune exhibits the greatest potential; nevertheless, its resources are not fully included in the product offer and are not reflected in full development of the geotourism function. A similar situation has been noted in the Susiec, Szczebrzeszyn, Tereszpol, and Goraj communes.

The function in the Zwierzyniec commune is excessively developed in comparison with the resources, which indicates that the area is overloaded by tourist movement.

The analysis of the values of partial, total, and general indices demonstrates that the value of the geotourism function index in most communes in the Roztocze TBR is influenced by the number of tourists visiting the resources. The most frequently proposed products are trails (cycling, trekking, walking, educational), including those associated with resources included in the linear product offer, i.e., the Central Roztocze Cycling Trail, the Central Roztocze Geotourism Trail, and the Szlak Szumów trail. The Museum of Petrified Trees in Siedliska and the Roztocze Green Velo Bicycle Rally are the most frequently mentioned products-objects and products-events, respectively.

The most numerous resources in the proposed offers are represented by the steep rapids in riverbeds (in 20 offers), viewpoint hills (13 offers), springs (12), loess gullies (9), the Miocene limestone quarry in Józefów (8), and the Museum of Petrified Trees in Siedliska (5). The range of the products is very similar, which is a result of the individual tourism business activity of most economic entities in the Roztocze region. Consequently, tourists are concentrated either in very small areas or in certain linear systems.

Given their current products or still unused resources, Józefów, Krasnobród, Susiec, and Lubycza Królewska communes have been found to have the greatest possibilities to exploit the geotourism potential of the Roztocze TBR with the prospect of establishment of the "Kamienny Las na Roztoczu" geopark.

The present results indicate that the method employed in the study can serve as an approach for assessment of the geotourism potential and function in any area. Its partial results can be the basis for determination of trends and possibilities of geotourism development in various spatial units.

Funding: This research received no external funding.

Institutional Review Board Statement: Not applicable. 
Informed Consent Statement: Not applicable.

Data Availability Statement: Not applicable.

Acknowledgments: I am grateful to unknown reviewers for their helpful comments and suggestions on the original version of the manuscript. These have helped in preparing an improved version of this paper.

Conflicts of Interest: The author declares no conflict of interest.

\section{References}

1. Bushell, R.; Staiff, R.; Eagles, P.F.J. Tourism and protected areas: Benefits beyond boundaries. In Tourism and Protected Area: Benefits Beyond Boundaries; Bushell, R., Eagles, P.J.F., Eds.; CABI International: Wallingford, UK, 2007; pp. 1-11.

2. Towards a Green Economy. Pathways to Sustainable Development and Poverty Eradication. A Synthesis for Policy Makers. UNEP. 2011. Available online: https://sustainabledevelopment.un.org/content/documents/126GER_synthesis_en.pdf (accessed on 15 November 2020).

3. Hall, C.M.; Piggin, R. World Heritage sites: Managing the brand. In Managing Visitor Attractions: New Directions; Fyall, A., Garrod, B., Leask, A., Eds.; Butterworth Heinemann: Oxford, UK, 2003; pp. 203-219.

4. Ryan, J.; Silvanto, S. The World Heritage site list: The making and management of a brand. Place Brand. Public Dipl. 2009, 5, 290-300. [CrossRef]

5. Ryan, J.; Silvanto, S.; Seitz, V. The promotion of UNESCO biosphere reserves as tourist destinations: A preliminary examination of trends and implications. Int. J. Bus. Glob. 2013, 10, 309-324. [CrossRef]

6. Gonzalez-Tejada, C.; Du, Y.; Read, M.; Girault, Y. From nature conservation to geotourism development: Examining ambivalent attitudes towards UNESCO directives with the global geopark network. Int. J. Geoherit. 2017, 5, 1-20. [CrossRef]

7. Ryan, J.; Silvanto, S. A brand for all the nations: The development of the World Heritage brand in emerging markets. Mark. Intell. Plan. 2011, 29, 305-318. [CrossRef]

8. Solon, J.; Borzyszkowski, J.; Bidłasik, M.; Richling, A.; Badora, K.; Balon, J.; Brzezińska-Wójcik, T.; Chabudziński, Ł.; Dobrowolski, R.; Grzegorczyk, I.; et al. Physico-geographical mesoregions of Poland-Verification and adjustment of boundaries on the basis of contemporary spatial data. Geogr. Political 2018, 91, 143-170. [CrossRef]

9. Roztoczański Park Narodowy. Available online: http://roztoczanskipn.pl/pl/45-aktualnosci/501-transgraniczny-rezerwatbiosfery-roztocze (accessed on 15 November 2020).

10. Roztocze Transboundary Biosphere Reserve, Poland/Ukraine. Available online: https://en.unesco.org/biosphere/eu-na/ roztocze (accessed on 15 November 2020).

11. Hawkins, D.E.; Lamoureux, K. Global growth and magnitude of ecotourism. In The Encyclopedia of Ecotourism; Weaver, D.B., Ed.; CABI Publishing: Wallingford, UK, 2001; pp. 63-72. [CrossRef]

12. Buckley, R.C. Case Studies in Ecotourism; CABI Publishing: Wallingford, UK, 2003.

13. Hose, T.A. European "Geotourism"-Geological interpretation and geoconservation promotion for tourist. In Geological Heritage: Its Conservation and Management; Barretino, D., Wimbledon, W.P., Gallego, E., Eds.; Instituto Tecnológico Geominero de España: Madrid, Spain, 2000; pp. 127-146.

14. Dowling, R.K. Global geotourism-An emerging form of sustainable tourism. Czech J. Tour. 2013, 2, 59-79. [CrossRef]

15. Farsani, N.T.; Coelho, C.; Costa, C. Geotourism and geoparks as novel strategies for socio-economic development in rural areas. Int. J. Tour. Res. 2011, 13, 68-91. [CrossRef]

16. Newsome, D.; Dowling, R.K.; Leung, Y.F. The nature and management of geotourism: A case study of two established iconic geotourism destinations. Tour. Manag. Perspect. 2012, 2-3, 19-27. [CrossRef]

17. Dowling, R.K. Geotourism's global growth. Geoheritage 2011, 3, 1-13. [CrossRef]

18. Neto de Carvalho, C.; Rodrigues, J.C.; Canilho, S.; Amado, S. Geopark Naturtejo, bajo los auspicios de la UNESCO: La construcción participativa de un destino geoturístico en Portugal. Tierra Y Tecnol. 2011, 40, 52-56.

19. Ólafsdóttir, R.; Tverijonaite, E. Geotourism: A Systematic Literature Review. Geosciences 2018, 8, 234. [CrossRef]

20. Bentivenga, M.; Cavalcante, F.; Mastronuzzi, G.; Palladino, G.; Prosser, G. Geoheritage: The Foundation for Sustainable Geotourism. Geoheritage 2019, 11, 1367-1369. [CrossRef]

21. Štrba, L.; Kolačkovská, J.; Kudelas, D.; Kršák, B.; Sidor, C. Geoheritage and Geotourism Contribution to Tourism Development in Protected Areas of Slovakia-Theoretical Considerations. Sustainability 2020, 12, 2979. [CrossRef]

22. Ólafsdóttir, R. Geotourism. Geosciences 2019, 9, 48. [CrossRef]

23. Lazzari, M.; Aloia, A. Geoparks, geoheritage and geotourism: Opportunities and tools in sustainable development of the territory. Geoj. Tour. Geosites 2014, 13, 8-9.

24. Dowling, R.K.; Newsome, D. (Eds.) Geotourism; Elsevier Butterworth-Heinemann: Oxford, UK, 2006.

25. Rodrigues, J.; de Carvalho, C.N.; Ramos, M.; Ramos, R.; Vinagre, A.; Vinagre, H. Geoproducts-Innovative development strategies in UNESCO Geoparks: Concept, implementation methodology, and case studies from Naturtejo Global Geopark, Portugal. Int. J. Geoheri. Parks 2021, in press. [CrossRef] 
26. Palladino, G.; Prosser, G.; Bentivenga, M. The geological itinerary of Sasso di Castalda: A journey into the geological history of the Southern Apennine thrust-belt (Basilicata-Southern Italy). Geoheritage 2013, 5, 47-58. [CrossRef]

27. Buckley, R.; Robinson, J.; Carmody, J.; King, N. Monitoring for management of conservation and recreation in Australian protected areas. Biodivers. Conserv. 2008, 17, 3589-3606. [CrossRef]

28. Brzezińska-Wójcik, T.; Skowronek, E.; Świeca, A. Diversity of the tourism potential and functions in the Roztocze region. Econ. Probl. Tour. 2017, 40, 65-81. [CrossRef]

29. Krapiec, M.; Jankowski, L.; Margielewski, W.; Urban, J.; Krapiec, P. The Stone Forest (Kamienny Las) Geopark in Roztocze and its geoturistic values. Prz. Geol. 2012, 60, 468-479.

30. Berthelsen, A. From Precambrian to Variscan Europe. In A Continent Revealed. The European Geotraverse; Blundell, D., Freeman, R., Mueller, S., Eds.; University Press: Cambridge, UK, 1992; pp. 153-164.

31. Malinowski, J.; Mojski, J.E. Mapa Geologiczna Polski 1:200,000, ark. Lublin, A—Mapa Utworów Powierzchniowych; Wydawnictwa Geologiczne: Warszawa, Poland, 1981.

32. Rzechowski, J.; Kubica, B. Mapa Geologiczna Polski 1:200,000, ark. Tomaszów Lubelski, Dołhobyczów. A-Mapa Utworów Powierzchniowych; Wydawnictwo Kartograficzne Polskiej Agencji Ekologicznej, S.A.: Warszawa, Poland, 1996.

33. Margielewski, W.; Jankowski, L.; Krapiec, M.; Garecka, M.; Hałas, S.; Urban, J. Analysis of reworked sediments as a basis of the Palaeogene-Neogene palaeogeography interpretation: Case study of the Roztocze region (SE Poland). Sediment. Geol. 2017, 352, 14-29. [CrossRef]

34. Cieśliński, S.; Kubica, B.; Rzechowski, J. Mapa Geologiczna Polski. 1:200,000, ark. Tomaszów Lubelski, Dołhobyczów. B-Mapa bez Utworów Czwartorzędowych; Wydawnictwo Kartograficzne Polskiej Agencji Ekologicznej, S.A.: Warszawa, Poland, 1996.

35. Buraczyński, J.; Krzowski, Z. Middle Eocene in the Sołokija graben on Roztocze Upland. Kwart. Geol. 1994, 38, 739-753.

36. Wysocka, A. Clastic Badenian deposits and sedimentary environments of the Roztocze Hills across the Polish-Ukrainian border. Acta Geol. Pol. 2002, 52, 535-563.

37. Kłusek, M. Fossil wood from the Roztocze region (Miocene, SE Poland)—A tool for palaeoenvironmental reconstruction. Geol. Q. 2006, 50, 465-474.

38. Buraczyński, J. Roztocze. Budowa-Rzeźba-Krajobraz; Zakład Geografii Regionalnej: Lublin, Poland, 1997.

39. Brzezińska-Wójcik, T.; Kociuba, W. Transformation of the Roztocze segment of the Wieprz river valley (SE Poland) in the Pleistocene. Prz. Geol. 2001, 49, 257-266.

40. Karczmarz, K.; Popiel, J.S. Wstępne badania nad flora górnokredową Roztocza. Ann. Umcs 1966, 21, $269-278$.

41. Halamski, A.T. Latest Cretaceous leaf floras from southern Poland and western Ukraine. Acta Palaeontol. Pol. 2013, 58, 407-443. [CrossRef]

42. Cieśliński, S. Szczegótowa Mapa Geologiczna Polski 1:50,000, ark. Zakrzówek (822); Państwowy Instytut Geologiczny: Warszawa, Poland, 1993.

43. Brzezińska-Wójcik, T. Morfotektonika w Annopolsko-Lwowskim Segmencie pasa Wyżynnego w Świetle Analizy Cyfrowego Modelu Wysokościowego oraz Wskaźników Morfometrycznych; Uniwersytet Marii Curie Skłodowskiej: Lublin, Poland, 2013; Available online: https:/ / books-box.com/katalog/wydawnictwo/wydawnictwo-uniwersytetu-marii-curie-sklodowskiej-w-lublinie? page $=16$ (accessed on 20 November 2020).

44. Pisera, A. Palaeoecology and lithogenesis of the Middle Miocene (Badenian) algal-vermetid reefs from the Roztocze Hills, southeastern Poland. Acta Geol. Pol. 1985, 35, 89-155.

45. Geostanowiska PIG-PIBCBDG. Available online: https://cbdgportal.pgi.gov.pl/geostanowiska/ (accessed on 20 November 2020).

46. Brzezińska-Wójcik, T.; Hnatiuk, R. Rzeźba terenu. In Rozłocze—Przyroda i Człowiek; Grabowski, T., Harasimiuk, M., Kaszewski, B.M., Kravchuk, Y., Lorens, B., Michalczyk, Z., Shabliy, O., Eds.; Roztoczański Park Narodowy: Zwierzyniec, Poland, 2015; pp. 75-91.

47. Kociuba, W.; Brzezińska-Wójcik, T. Zarys paleogeografii roztoczańskiego odcinka doliny Wieprza (SE Polska) w czwartorzędzie. Ann. Umcs 2002, 54, 49-82.

48. Superson, J. Funkcjonowanie Systemu Fluwialnego Wyżynnej Części Dorzecza Wieprza w Zlodowaceniu Wisty; Rozprawy Habilitacyjne Wydziału BiNoZ UMCS: Lublin, Poland, 1996.

49. Buraczyński, J. Les entailles d'erosion recentes (ravins) du Roztocze Occidental. Biul. Lubel. Tow. Nauk. 1965, 3, $23-26$.

50. Chmiel, S.; Michalczyk, Z.; Turczyński, M. Ocena jakości wód podziemnych i powierzchniowych Roztocza. Ann. UMCS 1997, 52, 77-102.

51. Ciężkowski, W.; Porwisz, B.; Zuber, A. Geneza i wiek wód siarczkowych Horyńca Zdroju i Ratoszyna. Wspótcz. Probl. Hydrogeol. 2003, 9, 95-102.

52. PIG-PIBCBDG. Available online: http://geostanowiska.pgi.gov.pl/gsapp_v2/ObjectDetails.aspx?id=2166 (accessed on 20 November 2020).

53. Roztoczański Park Narodowy. Available online: http:/ / roztoczanskipn.pl/pl/ (accessed on 26 November 2020).

54. Zespół Lubelskich Parków Krajobrazowych. Available online: https://parki.lubelskie.pl/ (accessed on 28 November 2020).

55. Lokalna Organizacja Turystyczna Roztocze. Available online: http:/ / roztoczewita.pl/ (accessed on 28 November 2020).

56. Lokalna Organizacja Turystyczna Zamość i Roztocze. Available online: https://pl-pl.facebook.com/LOTZamosciRoztocze/ (accessed on 28 November 2020). 
57. Józefowska Kawaleria Rowerowa. Available online: http://jkr.org.pl/ (accessed on 2 December 2020).

58. Polskie Towarzystwo Turystyczno-Krajoznawcze. Oddział w Zamościu. Available online: http://www.zamosc.pttk.pl/ (accessed on 5 December 2020).

59. Powiat Biłgorajski. Available online: https://www.bilgorajski.pl/ (accessed on 2 December 2020).

60. Powiat Lubaczowski. Available online: https:// powiatlubaczowski.pl/ (accessed on 12 December 2020).

61. Powiat Tomaszowski. Available online: https://www.powiat-tomaszowski.com.pl/ (accessed on 2 December 2020).

62. Powiat Zamojski. Available online: http://www.powiatzamojski.pl/ (accessed on 15 December 2020).

63. Gmina Batorz. Available online: http://www.batorz.gmina.pl/index.php/muzeum-wiejskie (accessed on 2 December 2020).

64. Restauracja Klemens. Available online: http://restauracjaklemens.pl/muzeum-skarbow-ziemi-i-morza (accessed on 5 January 2021).

65. Zagroda Guciów. Available online: https:/ /www.guciow.pl/muzeum (accessed on 5 January 2021).

66. Powiat Tomaszowski. Available online: https://www.powiat-tomaszowski.com.pl/aktualnosci/2020/06/muzeumskamienialych-drzew-w-siedliskach/ (accessed on 5 January 2021).

67. Najafabadei, M.E.; Kia, E.A.; Alizadeh, S.J.; Kefayatmotlagh, O. Assessment of ecotourism and geo-tourism potentials the Chahardangeh region (in the Mazandaran province) using the SWOT model. Cumhuriyet Sci. J. 2015, 36, 274-288.

68. Antić, A.; Tomić, N. Geoheritage and geotourism potential of the Homolje area (eastern Serbia). Acta Geotur. 2017, 8, 67-78. [CrossRef]

69. Pilogallo, A.; Nolè, G.; Amato, F.; Saganeiti, L.; Bentivenga, M.; Palladino, G.; Scorza, F.; Murgante, B.; Las Casas, G. Geotourism as a Specialization in the Territorial Context of the Basilicata Region (Southern Italy). Geoheritage 2019, 11, 1435-1445. [CrossRef]

70. Greco, S.; Ishizaka, A.; Tasiou, M.; Torrisi, G. On the Methodological Framework of Composite Indices: A Review of the Issues of Weighting, Aggregation, and Robustness. Soc. Indic. Res. 2019, 141, 61-94. [CrossRef]

71. Gołembski, G.; Nawrot, Ł.; Olszewski, M.; Zmyślony, P. Investment decisions in the early stages of the tourism area life cycle. Tourism 2010, 58, 361-377. Available online: https: / / hrcak.srce.hr/ 63594 (accessed on 17 February 2021).

72. Słomka, T. Geodiversity of Poland. Pol. Geol. Rev. 2008, 56, 584-587.

73. Ollier, C. Problems of geotourism and geodiversity. Quaest. Geogr. 2012, 31, 57-61. [CrossRef]

74. Derek, M. Funkcja Turystyczna Jako Czynnik Rozwoju Lokalnego w Polsce. Ph.D. Thesis, Wydział Geografii i Studiów Regionalnych UW, Warszawa, Poland, 2008. Available online: http://wgsr.uw.edu.pl/wgsr/wp-content/uploads/2018/11/1_pdfsam_ doktorat-w-pdf.pdf (accessed on 20 November 2020).

75. Durydiwka, M. Tourist function in rural areas of Poland. Spacial diversity and changing trends. Misc. Geogr. 2013, 17 , 5-11. [CrossRef]

76. Jafari, J. (Ed.) Encyclopedia of Tourism; Routledge: London, UK; New York, NY, USA, 2001.

77. Gierliński, G.D.; Ploch, I.; Gawor-Biedowa, E.; Niedźwiedzki, G. The first evidence of dinosaur tracks in the Upper Cretaceous of Poland. Oryctos 2008, 8, 107-113.

78. Jaroszewski, W. Sedymentacyjne przejawy mioceńskiej ruchliwości tektonicznej na Roztoczu Środkowym. Prz. Geol. 1977, 25, 418-427. Available online: https://geojournals.pgi.gov.pl/pg/article/view/21850/15533 (accessed on 28 December 2020).

79. Brzezińska-Wójcik, T. Strategia hands-on activity w kreowaniu geoproduktów w kontekście edukacji, interpretacji i promocji geodziedzictwa na Roztoczu (środkowowschodnia Polska). Ekon. Probl. Tur. 2015, 29, 169-193.

80. Urząd Marszałkowski Województwa Lubelskiego w Lublinie. Available online: https://promocja.lubelskie.pl/turystyka/ regionalne-szlaki-rowerowe/ (accessed on 27 December 2020).

81. Ponikiewski, A. Jaskiniowe Roztocze. Jaskinie 2009, 55, 28-30.

82. Stowarzyszenie Przyjaciół Roztocza “Jastrzębia Zdebrz". Available online: https://www.roztoczezachodnie.pl/lista_uczestnikow (accessed on 27 December 2020).

83. Sobolewska, A.; Sztanke, M.; Pasternak, K. Składniki borowiny i jej właściwości lecznicze. Balneol. Polska 2007, 49 , 93-98.

84. Michalczyk, Z. (Ed.) Źródła Roztocza; Uniwersytet Marii Curie Skłodowskiej: Lublin, Poland, 1996.

85. Wagrowski, A. Objaśnienia do Szczegótowej Mapy Geologicznej Polski 1:50,000, ark. Turobin (859); Wydawnictwa Kartograficzne Polskiej Agencji Ekologicznej, S.A.: Warszawa, Poland, 2001.

86. Green Velo. Available online: https://greenvelo.pl/detal/1171-greenvelo-trasa-rowerowa-gminy-zamosc-na-skraju-roztocza (accessed on 27 November 2020).

87. Miasto i Gmina Szczebrzeszyn. Available online: https:/ /www.szczebrzeszyn.pl/dla-turysty/ (accessed on 10 December 2020).

88. Gminny Ośrodek Kultury w Horyńcu-Zdroju. Available online: http://www.horyniec.naszgok.pl (accessed on 15 December 2020).

89. Hose, T.A. Geotourism and Interpretation. In Geotourism; Dowling, R., Newsome, D., Eds.; Butterworth Heinemann; Elsevier Science: Oxford, UK, 1995; pp. 221-241.

90. Kawałko, D. Józefowski ośrodek kamieniarski. In Przyczynki do etnografii Zamojszczyzny; Materiały Ogólnopolskiej Sesji PopularnoNaukowej w Zamościu: Zamość, Poland, 22-24.IX.1995 r.; pp. 46-61. Available online: http://biblioteka.teatrnn.pl/dlibra/ Content/11058/Przyczynki_do_etnografii_Zamojszczyzny.pdf (accessed on 15 January 2021).

91. Kaczmarek, J.; Stasiak, A.; Włodarczyk, B. Produkt Turystyczny. Pomyst, Organizacja, Zarzadzanie, 2nd ed.; Polskie Wydawnictwo Ekonomiczne: Warszawa, Poland, 2010. 